\title{
RYBNÍK DEMALKA. PŘÍSPĚVEK K OSÍDLENÍ SEVEROVÝCHODNÍ ČÁSTI ČESKOMORAVSKÉ VRCHOVINY VE STŘEDOVĚKU
}

\author{
MIROSLAV DEJMAL - JAN PETŘÍK - KATARÍNA ADAMEKOVÁ - LIBOR PETR - \\ MICHAELA PRIŠŤÁKOVÁ - MICHAL VÁGNER - PETR KOČÁR - MOJMÍR HRÁDEK - \\ ALEŠ BAJER
}

\begin{abstract}
Abstrakt: V povodi Bukovského potoka, mezi obcemi Střitež a Habří, byly během geologického průzkumu $v$ 90. letech 20. stoleti nalezeny pozůstatky zaniklého středověkého rybnika. Následný výzkum v letech 2015 a 2016 přinesl podrobnosti nejen o dosud neznámém středověkém vodním dile, ale diky dobře zachovanému environmentálnímu záznamu i o procesu osidlováni a vývoji krajiny v širším okolí od pravěku do novověku. Výsledky terénní práce jsme se pokusili shrnout v predkládaném př́spěvku, a to včetně zasazení do historického kontextu vzniku zdejšího vrcholně středověkého osidlení.
\end{abstract}

Klićová slova: Českomoravská vrchovina - vrcholný středověk - rybník - kolonizace - environmentální archeologie.

The Demalka fishpond. A contribution to the settlement of the north-east part of the Bohemian-Moravian Highlands in the Middle Ages

Abstract: The remains of a defunct medieval fishpond were discovered in the basin of the Bukovsky potok stream, between the villages of Střitež and Habří, during a geological survey in the 1990s. Subsequent research in 2015 and 2016 provided details not only about the previously unknown medieval pond but also, thanks to the well-preserved environmental record, about the settlement process and the development of the wider landscape from prehistory to the modern age. This paper seeks to summarize the results of the field survey and to set them in the historical context of the emergence of the local high-medieval settlement.

Key words: Bohemian-Moravian Highlands - high Middle Ages - fishpond - colonization - environmental archaeology.

Severovýchodní část Českomoravské vrchoviny leží mimo tzv. starou sídelní oblast. Nové archeologické výzkumy sice dokládají stále častěji pravěké a raně středověké nálezy z tohoto regionu, ovšem zdejší osídlení se od toho v úrodných nížinách značně lišilo. V rámci raného středověku pak samozřejmě nešlo o zcela pustou oblast. Nicméně pobyt člověka v těchto končinách je spojován hlavně s návazností na dálkové komunikace či s provozováním lesních řemesel a celkově s využíváním lesa. Sít' sídlišt' patrně nebyla př́liš rozvinutá a ani stabilní. Až v druhé polovině 12. století můžeme uvažovat o masovějším pronikání lidské činnosti do regionu tehdy pouze výjimečně či sporadicky využívaného.

Doposud byla při sledování počátku vrcholně středověkého osídlení v oblasti dominantní historie založená na písemných pramenech. Mohlo by se tedy zdát, že informace z písemných pramenů musely být již dávno vytěženy. Ovšem právě povaha písemných pramenů vždy bude umožňovat nové interpretace a výklady, nalézání nových souvislostí, přičemž tento proces nebude nikdy ukončen.

Archeologie, která převážně pracuje s hmotnými prameny, celkový obraz počátků a podoby osídlení severovýchodní části Českomoravské vrchoviny dosud spíše jen doplňovala. Zaměřila se zvláště na některé vybrané lokality, přičemž i v tomto regionu zůstaly mnohé provedené archeologické výzkumy bez bližšího vyhodnocení. Situaci pouze postupně mění rozvíjející se záchranné výzkumy, které při dnešním financování archeologie představují absolutní většinu prováděných terénních odkryvů. Jejich četnost a možnost zachytit v rámci záchranné archeologie informace $\mathrm{k}$ počátkům osídlení námi sledovaného regionu je přitom značně omezena faktem, že výzkumy zpravidla neprobíhají v rámci vesnic pod jednotlivými usedlostmi, kde lze předpokládat pozůstatky nejstarších středověkých sídel.

O to větší důležitost mají př́ípadné badatelské výzkumy, které mají primárně za cíl zodpovědět předem definované otázky. A lze při nich využít dnes již částečně etablovanou širokou paletu 
archeologicko-environmentálních metod výzkumu. Částečně byla takovým výzkumem i naše práce na zaniklém rybníku Demalka v povodí Bukovského potoka.

Impulzem k ní byl geologický výzkum z roku 1995. Během něho byl relikt dosud neznámého rybníka objeven. Došlo k základní sondáži tělesa hráze a k rámcové dataci (Hrádek 1995). V letech 2015 a 2016 proběhla sondáž s cílem ověření konstrukce a datace rybníka. Byly řešeny i další otázky související s funkcí rybníka, proměnami prostředí v době jeho existence a jeho zánikem. Výsledky paleoekologické analýzy odebraného vzorku profilu sedimentu rybníka a pohřbené nivy umožnily rekonstrukci podoby okolní krajiny, vegetace a lidských aktivit před založením rybníka a v průběhu jeho existence. Záměrem výzkumu bylo také poznání geomorfologických procesů v rámci Bukovského potoka. Cílem článku je tedy využít získaná data z poměrně jedinečné lokality k objasnění počátků kolonizace ve vrcholném středověku v severovýchodní části Českomoravské vrchoviny, a to za použití kombinace historických pramenů, archeologie a př́rodovědných analýz.

\section{Popis lokality}

Studovaný rybník je situován v nivě Bukovského potoka ve výšce přibližně $460 \mathrm{~m} \mathrm{n}$. m. (obr. 1), mezi obcemi Bukov a Střítež (k. ú. Stř́itež u Bukova, okres Žd’ár nad Sázavou). Nachází se

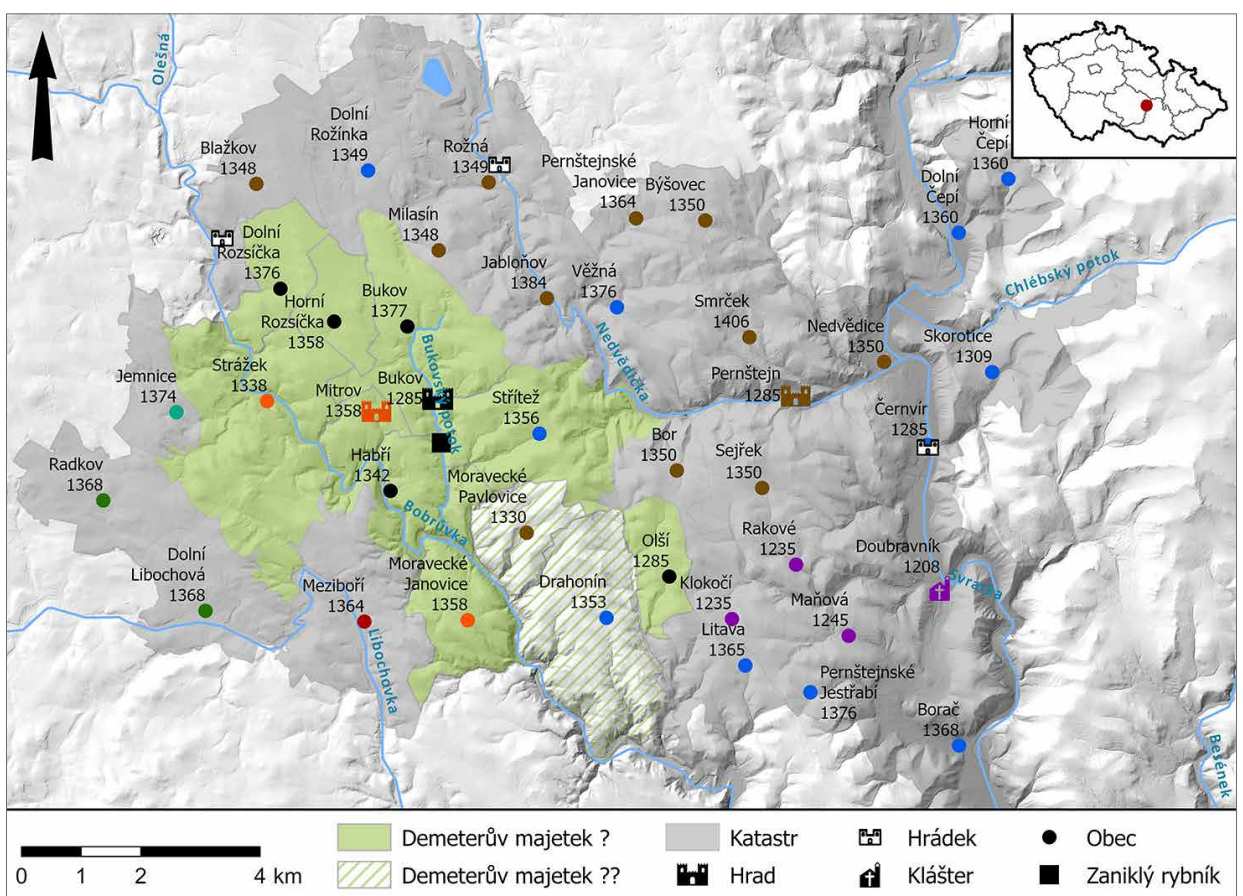

Obr. 1. Mapa sledované oblasti s rekonstrukcí možné pozemkové držby. Jednotlivé vesnice založené ve stř̌edověku jsou doplněny o letopočet první zmínky v písemných pramenech. Barevně je označena majetková př́slušnost vesnic při první zmínce. Hnědá - páni z Pernštejna; fialová - klášter v Doubravníku; oranžová - panství Mitrov; zelená - panství Moravec; tmavě zelená - panství Křižanov; červená - panství Osová; modrá - majetek drobné šlechty. Vyznačen je též hypotetický rozsah bukovského panství ve 13. století.

Abb. 1. Karte des beobachteten Gebietes mit Rekonstruktion möglicher Grundbesitze. Die einzelnen im Mittelalter gegründeten Dörfer wurden um die Jahreszahl ihrer ersten Erwähnung in den schriftlichen Quellen ergänzt. Die Besitzzugehörigkeit der Dörfer bei ihrer ersten Erwähnung wurde farblich gekennzeichnet. Braun - Herren von Pernstein; violett - Kloster in Doubravník; orange - Herrschaft Mitrov; grün - Herrschaft Moravec; dunkelgrün - Herrschaft Křižanov; rot - Herrschaft Osová; blau - Besitz des Kleinadels. Auch der hypothetische Umfang der Herrschaft Bukov im 13. Jahrhundert wurde gekennzeichnet. 
v severovýchodní části Českomoravské vrchoviny, na rozhraní geomorfologických celků Hornosvratecké vrchoviny a Křižanovské vrchoviny (Demek a kol. 2006, 154). Geomorfologie oblasti je ovlivněna vývojem údolí Bukovského potoka, který představuje 4,8 km dlouhý levobřežní přítok řeky Loučky (Bobrůvky) náležící povodí řeky Svratky. V údolí potoka převládají amfibolity doprovázené rulami, migmatity a granulity pestré skupiny strážeckého moldanubika. Byla zde zjištěna i siderit-sulfitová mineralizace spojená s př́itomností uranu (Doležalová-Losos 2004). Př́tomnost rudní mineralizace naznačuje možnost historické těžby drahých kovů. Kvartérní sedimenty jsou zastoupeny zejména fluviálními, deluvio-fluviálními a deluviálními sedimenty (Stárková 2000).

Současná vegetace je tvořena mozaikou polí, luk a lesů. Lesní vegetaci tvoří především smrkové monokultury, v současné době v různém stadiu rozpadu v důsledku kůrovcové kalamity. Častá je výsadba monokultur borovice. $Z$ původních jedlo-bukových lesů nezůstalo téměř nic, pouze ojediněle je zastoupen buk. Listnaté dřeviny se vyskytují hlavně v údolní nivě, jedná se o porosty s výskytem javoru, lísky, lípy, ojediněle jilmu s pionýrskými dřevinami, jako jsou topol, osika a bříza. Podél potoka roste olše s vrbou a topolem. Nelesní vegetace je tvořena travními porosty, které jsou dnes využívány jako pastviny nebo jsou sečeny z důvodů zemědělských dotací. Vlhké louky $\mathrm{v}$ nivě s výskytem tužebníku (Filipendula ulmaria) jsou rovněž obhospodařovány sečením nebo pastvou.

Údolní niva je přehrazena př́íným valem, který byl rozpoznán M. Hrádkem (1995) jako hráz zaniklého rybníka. Koruna hráze se zvedá oproti povrchu před hrází o 0,5-0,7 m, za hrází je to až o $3 \mathrm{~m}$. Přímý úsek dnešního koryta podél pravé strany nádrže je nejspíše umělý a byl zřejmě vykopán jako součást výstavby bočního (obtočného) rybníka. Původní koryto, probíhající středem nivy, bylo zjištěno pod nánosy rybníka (1995). V rámci původního geomorfologického výzkumu zde byla strojově vyhloubena rýha, která zachytila konstrukci hráze včetně dřevěných prvků. $\mathrm{Z}$ dřevěné piloty nalezené na vnitřním okraji hráze (berma rybníka?) bylo zjištěno neuzavřené dendrochronologické datum smýcení po roce 1194 (Kyncl 1995; 1995a). Původní radiokarbonové datování z dřevěného špalku (GD7745, 510 × 150 BP) nalezeného v úrovni dna po kalibraci indikuje velmi široký časový interval mezi 13. a 17. stoletím.

\section{Historický rámec}

Předně je tř̌ba konstatovat, že pravděpodobná doba založení rybníka, tak jak je stanovena na základě přírodovědných metod, spadá do období s minimem písemných pramenů, které máme pro zkoumanou oblast k dispozici. Osvětlit, kdo rybník založil či ve středověku vlastnil, je tak na základě písemných pramenů téměř nemožné. Nicméně je možné sledovat celkový historický kontext a pokusit se z něho dovodit možné odpovědi na tyto otázky. Torzálnost pramenů pro celé 13. a i většinu 14. století nás bohužel nutí často postupovat retrospektivně a snažit se o hypotetickou rekonstrukci stavu na počátku 13. století na základě mladších informací. Jsme si vědomi křehkosti těchto konstrukcí, ovšem nedostatek pramenů neumožňuje jiný prŕístup. Postupně se tedy budeme krátce věnovat počátkům osídlení v okolí, hradu Bukovu a osobě Demetera z Bukova, možné velikosti jeho panství, svobodným dvorům a svobodníkům v okolí, dolování a samozřejmě zmínkám o samotném rybníku.

Počátky stř̌edověkého osídlení v okolí námi zkoumaného rybníka jsou složitou otázkou, která značně přesahuje rozsah a záměr tohoto článku. Pouze shrňme základní fakta a vývody jednotlivých novějších prací, které se problematiky dotkly. Celá oblast nepatří ke staré sídelní oikumeně. Mladohradištní nálezy registrujeme nejbliže na Tišnovsku a v povodí řeky Svratky (Belcredi a kol. 1989, 182, map. XI; Doležel 1996, 69). K osídlení zkoumaného území došlo až $\mathrm{v}$ rámci kolonizačního procesu v závěru 12. a v 13. století, přičemž zdejší sídlištní struktura se dotvářela patrně ještě ve 14. století. Jak se zdá, ze západního směru postupovala kolonizace v režii majitelů křižanovského panství. Na jihu pak další směr představovaly majetky pánů z Deblína, prŕpadně Ronovců sedících na Osové. Na sever od námi zkoumaného území se realizovali páni erbu zubří hlavy, pozdější Pernštejnové. Patrně př́imo na osídlení prostoru, kde se rybník nachází, 
se podíleli páni erbu křídla, souhrnně označovaní jako Tasovci, podle nejčastějšího osobního jména rodu (Plaček 1987, 245-254; Poláček 1990, 407-425).

Takto lze charakterizovat situaci pro 13. století, a patrně pro jeho pokročilejší část. Avšak netušíme, jak vypadala situace ve 12 . století. Území, které bylo nejspíše pusté, či jen s minimem osídlení, které se mohlo vázat na průchozí komunikace a lesní řemesla, patřilo nejspíše přímo zeměpánovi. Své majetky zde měla patrně i církev, minimálně olomoucké biskupství. Alespoň to by naznačovala listina hlásící se do roku 1208 (CDB II, 73 č. 78). Listina je zrejejě falzem z doby těsně před polovinou 13. století (Štarha 2003, 35, pozn. 23), ale snad zachycuje reálně proběhlou směnu, která se udála mezi olomouckým biskupstvím a Štěpánem z Medlova, předkem pánů z Pernštejna. Ti tehdy patrně získali celé území okolo dnešního Doubravníka a Nedvědice, ovšem převážně jen na pravobřeží Svratky. Tato směna tak dokládá i biskupský majetek, který se zde ve 12. století musel nacházet. S touto první časovou vrstvou patrně souvisí kolonizační proud, který postupoval podél řeky Svratky. Nicméně celkově se zdá, že rozhodující měrou proběhla kolonizace celé oblasti v režii předních šlechtických rodů. A pro námi zkoumanou výseč v povodí Bukovského potoka mají zřejmě rozhodující význam právě příslušníci rodu erbu křídla - Tasovci. Konkrétně známe jednoho př́íslušníka tohoto rodu, který vlastnil i blízký hrad Bukov, a to Demetera, ${ }^{1}$ proto se u něho krátce zastavme.

Demeter z Bukova byl s největší pravděpodobností př́slušník rodu erbu křídla, jak dobře dokládají jeho pečetě přivěšené pod jediné dvě listiny, v nichž se jistě jeho jméno vyskytuje. Prvá je přivěšena pod biskupskou konfirmaci patronátního práva v Olší z roku 1285. Listina sice není prosta některých problémů, jako např́klad proč je pod biskupskou konfirmací přiložena právě Demeterova pečet'. Nicméně není důvod údaje v listině ani pečet' považovat za falešné (CDM IV, 296 č. 226; Juřička 2017, 10; pochybnosti o ní má Sadílek 2014, 28-30; Smolová 2009, 19-20, 29 , č. 2, naopak její text přiřazuje stálému biskupskému písaři). Druhá listina je z roku 1295. Jde opět o biskupskou konfirmaci patronátního práva, tentokráte v Deblíně. V opisu pečetě se sice Demeter píše již po Deblínu, nicméně pečet' opět nese znak orlího křídla (CDM V, 5 č. 5; RBM II, 726 č. 1689; Juřička 2017, 11, pozn. 25; Jan 1995, 5, 7). Jak vidíme, sám Demeter asi nebyl velkým příznivcem psaných listin, nebo se nezachovaly. Jeho samého asi musíme považovat za př́islušníka nějaké vedlejší větve Tasovců, která patrně vymřela již na konci 13. století. Hypoteticky by Demeterovým otcem, či př́ibuzným, mohl být Tas zmíněný v listině z roku 1235 (CDM V, 227 č. 14; viz níže). Zda měl Demeter mužské potomky, není známo; pokud existovali, nemuseli se dožít dospělého věku. Existenci mužského potomka ovšem předpokládá L. Jan, a to na základě listiny z roku 1297. Ta je sice označena jako Bočkovo falzum, nicméně L. Jan předpokládá, že osoby uvedené v listině existovaly a že zde uváděný Bohuš, kterého známe z roku 1358, by mohl být synem Demetera z prvního manželství (CDM IV, 296 č. 226; Jan 1995, 7; Šebánek 1936, 489-491). Demeter si někdy před rokem 1295 vzal za manželku výše zmíněnou Gertrudu z Deblína. A právě po Deblíně se v roce 1295 píše. Své hlavní sídlo tedy přenesl sem a změnil svůj predikát. Pro jeho držbu Bukova a okolí to ovšem nemuselo nic znamenat. V roce 1299 již nebyl Demeter na živu, jelikož tehdy se jeho žena Gertruda připomíná jako vdova. A to nejen po něm, ale i po svém dalším manželovi. Stihla tedy během těchto čtyř let pochovat jednoho manžela, znovu se vdát a ještě znovu ovdovět (Jan 1995, 6).

Demeter je tedy jediným známým majitelem hradu Bukova, někdy nehistoricky označovaného jako Lísek. Nevelký hrad je tvořen jádrem o rozměrech zhruba $40 \times 30 \mathrm{~m}$. Jádro je obkrouženo př́íkopem a valem. Původní předhradí se mohlo nacházet jihozápadně od hradního jádra. V prostoru jádra se zachovaly zbytky kamenné architektury.

Vzhledem $\mathrm{k}$ absenci písemných pramenů, kromě jediné zmínky $\mathrm{v}$ predikátu z roku 1285 (CDM IV, 296 č. 226; Michal 1983, 175-183), je klíčová datace existence hradu. Mohlo by se zdát, že na tuto otázku nebude těžké odpovědět, jelikož Bukov, jako jeden z mála našich hradů,

$1 \mathrm{~V}$ pramenech uváděn jako Demetrius, což by odpovídalo i dnešním pravidlům českého jazyka. Nicméně v literatuře je tato osoba, patrně pod vlivem slovenštiny, uváděna jako Demeter. Této varianty křestního jména se také my budeme držet. 
byl podroben poměrně rozsáhlému archeologickému výzkumu. Opak je však pravdou. Výzkum započal v roce 1983 a v různém rozsahu pokračoval až do roku 1990. Výzkum tehdy prováděl seminář dějin umění FF MU, a to pod vedením Zdeňka Kudělky a Lubomíra Konečného. Počátek výzkumu byl spojen s tehdejším projektem „Románská architektura na Moravě“ (Kudělka 1982-1983, 79-80; 1984-1985, 29-31; 1988-1989, 64-65; 1990-1992, 184-185). S odstupem času můžeme tento odkryv hodnotit jako značně rozporuplný. Nejenže se výzkum nedočkal nikdy ani základního zpracování. Zarážející je i fakt, že odkryté části hradních staveb byly vystaveny erozi či byly dosti neodborně konzervovány. Datace, které se objevily v krátkých zprávách o výzkumu či v pozdější literatuře, jsou značně problematické. Jsou totiž vyvozeny z nepublikované nálezové situace a často postaveny na chronologicky málo citlivých prvcích. Zpočátku rané datování hradu Z. Kudělka dedukoval na základě způsobu zdění věže v čele hradu - takováto datace je dnes již zcela nedostatečná a metodicky nepř́ípustná (Kudělka 1982-1983, 79-80). Navíc charakter zdiva ovlivnil patrně místní kámen (Dvořák-Unger 1996, 513-515). Později byly počátky hradu kladeny do druhé a třetí čtvrtiny 13. století, a to údajně i na základě nálezů. Tuto dataci měl potvrzovat také nález části ostění portálu, které autoři výzkumu kladli do 20.-30. let 13. století (Kudělka 1984-1985, 29-31). Datace podle nalezených artefaktů ovšem bohužel není k dispozici. Artefakty nebyly nikdy ani dílčím způsobem publikovány a jsou již nedostupné. ${ }^{2}$ Obecně se dnes prijímá datace vzniku hradu Bukova někdy okolo poloviny 13. století, přičemž k jeho zániku mohlo dojít někdy okolo roku 1300 či krátce po něm (Plaček 2001, 146-147). Stejnou dobu zániku předpokládali už vedoucí výzkumu.

Kromě výše uvedených prací se hradem Bukovem zabýval i J. Sadílek (2014). Podařilo se mu shromáždit četné informace o hradě a zdejším archeologickém výzkumu, i když ani on neměl prístup k materiálu $\mathrm{z}$ hradu a k dokumentaci z výzkumu, vyjma několika fotografií. Jeho četná pozorování a vývody značně rozšiřují znalosti o hradě a lze je téměř bez výhrad přijmout. Ovšem v některých věcech s ním nemůžeme souhlasit. At' pro neprokazatelnost jeho teorií, či někdy až násilné konstrukce, jimiž se snaží, bez původní dokumentace, podpořit své teorie. Zvláště bez pevnějších argumentů a indicií je dle nás vyslovena teorie o zeměpanském založení Bukova, kdy Demeter měl být pouze zdejším purkrabím (Sadílek 2014, 89). J. Sadílek přistoupil k dataci hradu následovně. Částečně uvádí dataci do 30 . let 13. století, kdy v podstatě přijímá Kudělkovu dataci architektonických článků (tamtéž, 85-86). V závěru pak počítá i s možností 30. a 40. let 13. století (tamtéž, 103). Jediné chronologicky citlivé nálezy, o kterých víme, je pět brakteátů, které jsou bez bližšího popisu a určení kladeny do třetí čtvrtiny 13. století (Kudělka 1990-1992, 184). At' se má situace okolo datování hradu jakkoliv, předpokládáme, že hrad je mladší než námi zkoumaný rybník. Mohl vzniknout až v druhé polovině 13. století, přičemž přesnější dataci může přinést teprve moderní zpracování již získaných artefaktů či nové výzkumy.

I když je hrad Bukov mladší než zkoumaný rybník, předpokládáme, že se později stal centrem panství či majetku, do něhož rybník patřil. Nabízí se tedy otázka, jak mohl být veliký tento majetkový díl, který později vlastnil i Demeter. Jistě k němu můžeme počítat hrad Bukov a asi i nejbližší vesnice. Z listiny z roku 1285 vyplývá, že mezi majetky Demetera patřilo i Olší. Nicméně další informace o jeho statcích v okolí hradu Bukova nemáme. Velkým problémem je fakt, že většina okolních vesnic se začíná v pramenech objevovat až okolo poloviny 14. století, přestože již často existovaly patrně o století dříve. Pokusme se i tak z jistých náznaků rekonstruovat možný rozsah Demeterových majetků (obr. 1).

Jistou indicií staršího rozdělení před Demeterovou dobou může být listina z roku 1235 (CDM V, 227 č. 14 - edice originálu; CDB III/1, 147 č. 119 - edice biskupská konfirmace). Zde jsou při darování vesnice Sess - dosud přesvědčivě nelokalizované historickým bádáním markrabětem Přemyslem doubravnickému klášteru potvrzeny i jeho majetky, které obdržel od Štěpána z Medlova. Přímo v okolí Doubravníka se jedná o Maňov, Klokočí, Rakové a Bořinov. Všechny tyto lokality se nacházejí na pravobřeží Svratky. Pro nás je i velice zajímavá formulace,

2 Materiál z výzkumu by se měl údajně nacházet stále u jednoho z vedoucích výzkumu L. Konečného. 
že kromě těchto vesnic náleží klášteru veškeré mýtiny či nově založené pozemky na této straně řeky až k pozemkům Tasovým. Tas je velice časté rodové jméno u rodu erbu křídla, ke kterému náležel i Demeter. O kterého Tasa by se mohlo jednat, ale z listiny není zřejmé. V pramenech se sice nějaký Tas v letech 1228-1234 objevuje, ale není jasné, o koho jde a jestli jím je míněn v listině uvedený Tas. Obecně byla celá věc vysvětlována tak, že jsou asi myšleny majetky na levobřeží, jež by později náležely k Lomnici, která již tehdy byla v rukou Tasovců (Štarha 2003, 35, pozn. 23). Nicméně text listiny i její konfirmace celkem explicitně uvádějí, že zmíněné mýtiny či nově vyklučené pozemky se mají nacházet na stejné straně řeky jako výše uvedené vesnice (CDB III/1, 147 č. 119; CDM V, 227 č. 14). Pokud tomu opravdu bylo tak a pokud by zmíněný Tas opravdu náležel k jednomu z předků Tasovců, pak by se mohlo jednat o doklad držby území okolo hradu Bukova a vesnice Olší nějakými předky či př́ibuznými Demetera již před polovinou 13. století. Právě Olší totiž navazuje na výše uvedené klášterní statky ze západní strany. Můžeme tedy uvažovat o tom, že majetky okolo hradu Bukova mohl Demeter zdědit po předcích či př́íbuzných.

Ze severovýchodní strany je rozsah Demeterova možného majetku poměrně dobře vytyčen rozsahem majetků pánů z Pernštejna. Jejich předek Štěpán z Medlova získal majetky v okolí dnešní Nedvědice na počátku 13. století. K roku 1208 se hlásí již výše zmíněná listina biskupa Roberta o směně majetků mezi biskupstvím a Štěpánem z Medlova, jíž měl Štěpán získat právě okolí Doubravníka a dnešní Nedvědice (CDB II, 73 č. 78). Jak jsme uvedli, listina samotná je falzum vzniklé patrně mezi lety 1240-1250. Nicméně sama směna se patrně odehrála tak, jak je v listině uvedeno (Štarha 2003, 31-32). Centrem panství se později stal hrad Pernštejn, který je poprvé zmíněn v predikátu Štěpána v roce 1285, právě při darování patronátního práva v Olší (CDM IV, 296 č. 226). Za součást pernštejnské držby v 13. století pak asi můžeme považovat okolí hradu včetně vesnic Sejřku, Boru, Smrčku, Rožné a Blažkova. Nad Rožnou je dochován i zbytek hrádku, který existoval v patrně v druhé polovině 13. století (Poláček 1990, 407-409; Sadílek 1997, 234-235). M. Plaček dokonce uvažuje o tom, že se mohlo jednat o prvotní sídlo Štěpána z Medlova a jeho potomků, ještě před stavbou Pernštejna (Plaček 2001, 547-548). Naopak J. Sadílek počítá s možností, že hrádek hlídal dosud jen hypoteticky předvídanou těžbu zlata okolo nedaleké osady Zlatkov (Sadílek 2014, 13). V roce 1349 je Rožná uváděna jako součást zubštejnského panství (ZDB I, 7 č. 122). Bud' jak bud', snad můžeme předpokládat, že ve 13. století náležela k majetkům rodu erbu zubří hlavy. Podobná situace jako v př́ípadě Rožné panuje i u Blažkova. Ten se také připomíná jako součást zubštejnského panství, a to v roce 1348 (ZDB I, 1 č. 2). Také u Blažkova stojí zbytky drobného opevněného sídla. Nicméně z důvodu absence historických zmínek neznáme jeho dataci, a tedy nevíme, zda ještě spadá do 13. století, jak by naznačoval jeho charakter, nebo zda sloužilo až zdejší drobné šlechtě, která se po Blažkovu píše ve 14. století (ZDB II, 19 č. 141-142; ZBD III, 30 č. 198; Plaček 2001, 104). Poněkud vzdáleny od ostatních pernštejnských držav leží Moravské Pavlovice, které ale asi také patří mezi jejich původní majetky, jak to alespoň naznačuje údaj k roku 1350 (ZDB I, 9 č. 151). Otázkou ovšem je, zda původně nenáležely k Demeterovým statkům a do majetků Pernštejnů se dostaly až později.

Výše uvedenými majetky, které byly patrně v držení Pernštejnů, lze tedy vymezit možnou hranici původního bukovského panství na části východní strany a na straně severní. Ze západu pak nejspíš k majetkům Demetera nepatřila již ves Jemnice, která se v roce 1374 vzpomíná jako patřící k Moravci. Stejně tak tomu bylo patrně s Radkovem a Dolní Libochovou, které v roce 1368 náležely ke Křižanovu (CDM X, 80 č. 53). Snad byly součástí křižanovského zboží již dříve. Pro nás není bez zajímavosti, že Křižanov byl tehdy v držení Tasovců, tedy stejného rodu, ke kterému patřil i Demeter. Nicméně se zdá, že Křižanov získali až někdy před rokem 1333, tedy nejspíše až po Demeterově smrti, patrně koupí od pánů ze Švábenic (Juřička 2017, 53; Futák-Plaček 2006, 44). Podobně k Bukovu nepatřilo asi i jižně ležící Meziboří, které je v roce 1364 zmiňováno jako součást panství osovského (ZDB V, 77 č. 109).

Kromě výše zmíněných vesnic, které patrně náležely původně k větším majetkovým celkům, je v okolí Bukova i několik vesnic, které do světla písemných pramenů rovnou vstupují jako 
majetek nižší šlechty. Jedná se o Pernštejnské Jestřabí, poprvé zmiňované v roce 1376 (ZDB VI, 115 č. 271), a také o v roce 1365 zmíněnou Litavu (ZDB IV, 55 č. 214), která je snad východiskem drobného rodu místních vladyků po ní se píšícího. Východně od Bukova je to pak Věžná, zmíněná v predikátu Alberta z Věžné v roce 1376 (ZDB VI, 120 č. 366). Bezprostředně u hradu Bukova se nachází Stř́itež doložená k roku 1356 (ZDB III, 29 č. 185). Na severu pak majetek drobné šlechty uzavírá Dolní Rožínka, doložená k roku 1349 (ZDB I, 3 č. 37). Mezi majetky drobné šlechty snad patřily i dnes zaniklé Žebratice, které jsou zmiňovány k roku 1368, snad měly stávat někde u Moravských Pavlovic (ZDB V, 77 č. 118). Ovšem ty dnes nedokážeme lokalizovat. Obecně ale nevíme, zda většinovými držiteli těchto pozemků nebyli například Pernštejnové, přičemž drobná šlechta zde držela pouze díly vesnic.

Naopak za součást původního bukovského panství snad můžeme považovat pozdější panství hradu Mitrova, který měl Bukovský hrad nahradit, i když při Mitrovu patrně zůstala jen část $\mathrm{z}$ dřívějších majetků. Již z názvu hradu Mitrova se usuzuje na odkaz k původnímu majiteli Bukova Demeterovi (Demetrius). Hrad samotný snad vznikl v první polovině 14. století (Poláček 1990, 426-428), možná právě jako náhrada za opuštěný Bukov (Plaček 2001, 147, 394-396; proti tomu se staví Sadílek 2014, 102). První zmínka je z roku 1358, kdy se po něm píše Bohuslav (ZDB III, 31 č. 230). V tomto deskovém zápise jsou uvedeny i vesnice tehdy k Mitrovu náležející. Jde o Strážek, Boleboř (dnes součást Strážku), Moravské Janovice a poněkud dále ležící Bojanov. První tři snad můžeme počítat do původního bukovského zboží. Spornější je otázka Bojanova. Nejasný je vztah Bohuslava, který asi náležel k rodu pánů z Vickova, k Demeterovi. Teoreticky mohli být př́ibuzní z ženské strany. Bohuslav mohl získat majetky sňatkem nebo dědictvím, nebo mohl být Demeterovým synem, jak jsme již výše uvedli s odkazem na L. Jana $(1995,7)$. Z Bohuslavových př́ibuzných známe patrně jeho bratry Bernarda a Archleba, v jejich predikátech je pak prvně doložena existence hradu Víckova (Bernard z Víckova 1340 - CDM VII, 196 č. 270; Archleb z Víckova 1346 - CDM VII, 486 č. 661). Sám Bohuslav se ještě v roce 1358 píše po Víckovu (ZDB III, 38 č. 431, poprvé v roce 1351 - ZDB II, 15 č. 45). Právě v roce 1358 proběhla zajímavá transakce, Bohuslav převedl na Buška II. (st.) z Mostiště svůj statek Víckov s hradem a vesnicí, dále ves Žd’árec, Vratislávku a zaniklý Holánkov. Převod měl být platný pouze po dobu života Buška, a pouze pokud by zemřeli Bohuslav i jeho syn Záviš bez dědiců, mohl si Bušek panství ponechat (ZDB III, 38 č. 431; Juřička 2017, 58). O blízkých vazbách také napovídá, že již v roce 1351 Bušek ustavil Bohuslava případným poručníkem svého majetku a svých dětí. Blízkost těchto dvou osob je pro nás zajímavá, jelikož páni z Mostiště patří k jednomu z rozrodů Tasovců. Tedy stejného rodu jako byl Demeter.

Pokud předpokládáme, že mitrovské panství tvořilo část původního majetku náležejícího k Bukovu, není vyloučeno, že Víckov se svými majetky mohl náležet k Demeterovým statkům. To již dávno předpokládal M. Plaček (1987, 246-249), ovšem M. Juřička spíše předpokládá, že Demeter neměl dědice a jeho majetky přešly na zeměpána jako odúmrt' $(2017,12)$. Do rodiny pánů z Víckova by se tak mitrovské zboží dostalo patrně od panovníka. Př́ípadně pokud bychom přijali hypotézu L. Jana, by Bohuš panství získal od Demetera jako jeho syn.

Dalším obtížně uchopitelným dílkem složité skládanky zdejšího středověkého osídlení jsou tř́i vesnice v bezprostř̌edním okolí hradu - Habří a Dolní a Horní Rozsíčka. Tyto vesnice představují jisté specifikum. Byly totiž asi původně složeny pouze ze svobodných dvorů, jejichž vlastníci jednotlivé majetkové převody zapisovali do zemských desk. Majitelé těchto usedlostí tedy byli svobodní a krom zeměpána nad sebou neměli patrně ve středověku žádnou vrchnost (Graus 1957, 200; Macek 2002, 394). J. Mezník je sice přiřadil k nižší šlechtě (1992, 440-441), ale je otázka, zda je na místě takto tuto skupinu klasifikovat (Vohryzek 2020,60). Problém těchto svobodných lidí není stále uspokojivě objasněn. Zvláště otázka, kdy došlo ke vzniku této svobodné, ale možná neurozené vrstvy (Jan 2019, 95-96). Z našeho pohledu se dost zásadně liší od okolní dobové nižší šlechty, a proto je musíme chápat jako samostatnou skupinu. Pro nás jsou důležité opět první zmínky. Dolní Rozsíčka se poprvé zmiňuje v roce 1358 (ZDB III, 30 č. 198), Horní snad patrně 1376 (ZDB VI, 120 č. 377). Samotné Habří, na jehož historickém území se rybník, o nějž nám 
jde, nachází, se připomíná k roku 1342 (CDM VII, 314 č. 432). Právě u této listiny se musíme na chvíli zastavit. Jde o listinu tehdejšího markraběte Karla, pozdějšího krále Karla IV., ve které daruje Bronislavovi Zilemu dvůr v Habří a jeden lán v Žabětíně. Držba je dědičná a Bronislav má sloužit za obvyklých podmínek. Pro nás je důležité, že darovaný majetek patřil k zeměpanskému hradu Veveří. $Z$ mnoha variant se nabízí dvě možnosti, proč tomu tak je. Prvá je podle nás méně pravděpodobná, totiž že Habří a potažmo i Rozsíčky patřily ke starým zeměpanským majetkům, které byly spravovány z nejbližšího zeměpanského hradu před polovinou 14. století, tedy z Veveří. Nám ovšem zeměpanská kolonizace v okolí Bukova, která by navíc neměla žádné zázemí v podobě opevněného sídla či centra panství a zároveň se neodrazila v písemných pramenech, přijde nepravděpodobná. Naopak výše zmíněné teorii J. Sadílka by takovýto scénář vyhovoval (Sadílek 2014, 89). Podle nás je pravděpodobnější, že ke vzniku svobodných dvorů došlo v okolí Bukova až ve 14. století, kdy snad bylo původní bukovské panství po nějakou dobu v držení zeměpána. Tomu se dostává zdejší panství do vlastnictví snad jako odúmrt. To by znamenalo, že Demeter neměl dědice. Přirozeně nemůžeme vyloučit ani jinou formu nabytí. Právě vzdálené majetky, tehdy snad bez správního centra, mohly ideálně posloužit k darování i neurozeným služebníkům, jejichž status měl být z nějakého důvodu svobodný, či mohli sloužit jako manové. Časově se tak stalo patrně v první polovině 14. století, kdy jediným dokladem je listina z roku 1342 pro Habří. Obě Rozsíčky jsou pak doloženy až deskovými zápisy, kdy docházelo ke změně majitelů dvorů, snad až v linii potomků obdarovaných. Že se dvory týkaly více vesnic ve sledované oblasti, dokládá ještě pozdní urbář pernštejnského panství z roku 1588. Zde se majitelé dvorů ukrývají již pod novověkým označením dvořáci. Pro Habří se uvádějí tři, v Blažkově dva, v Dolní Rozsíčce dva, v Horní Rozsíčce čtyři a v Bukově jeden (MZA, F 78, č. 344, f. 309r). Samozřejmě že všechny tyto dvory nemusely vzniknout ve 14 . století, a asi ani nevznikly.

Pro rozvoj regionu hrála patrně velkou důležitost i těžba rud, hlavně polymetalických za účelem získávání stř́ibra. Těžba patrně akcelerovala či v některých případech spouštěla kolonizační proces. V okolí námi zkoumané lokality se nachází hned několik dokladů středověké těžby. Patrně nejvýznamnější dobývání stříbrné rudy probíhalo v okolí Štěpánova nad Svratkou, tedy asi deset kilometrů vzdušnou čarou odtud. Těžební aktivity jsou doloženy od Horního Čepí až po Koroužné (Houzar 2020, 7), přičemž nejvýznamnější lokalitou je Havírna u Štěpánova. Zdejší těžba probíhala někdy od poloviny 13 . století a posléze i po část 14 . věku, kdy došlo patrně k jejímu útlumu (Doležel-Sadílek 2004, 43-119; Doležel 2020, 72-112).

Nedalekou důlní činnost v okolí ve 13. století dokládá i královská listina z roku 1252 či 1253. Sice se jedná nejspíše o falzum, ale patrně dobové. Je v něm mezi majetky doubravnického kláštera zmiňován i blíže nelokalizovaný stříbrný důl, který musel ležet někde mezi Doubravníkem a Olším, pokud nebyl totožný s výše uvedenými doly u Štěpánova (CDB IV, 488 č. 293; Doležel-Sadílek 2004, 79; k listině Teplý 2016, 49-51, k pravosti hlavně pozn. 65). J. Teplý ovšem uvažuje, že zmiňovaný důl se nacházel poblíž bezejmenné kóty $557 \mathrm{~m} \mathrm{n}$. m. mezi Dolním a Horním Čepím. Těžbu může připomínat i zdejší pomístní název Stříbrné štoly (Teplý 2016, 51-53). Př́ípadné stopy těžby nebyly na místě zatím ani zdokumentovány a př́ípadná těžba může pocházet i z mladšího časového úseku než ze 13. století. Př́ílušnost k doubravnickému klášteru také poněkud zpochybňuje poloha na levobřeží Svratky - jak jsme si ukázali již výše, původní majetky kláštera se patrně nacházely na pravobřeží.

Ze vzdálenějších lokalit lze zatím zmínit přesně nelokalizované, ale prameny $\mathrm{k}$ roku 1364 doložené dolování na osovském panství, patrně někde u Skřinažova (Doležel-Sadílek 2004, 78; ZDB IV, 50 č. 104). Další důlní práce, tentokráte snad spojené s dobýváním železných rud probíhaly přímo v okolí nedalekého hradu Pernštejna a na katastru Věžné. Přestože zdejší těžba spadá ve svém nejstarším horizontu do 16. a 17. století, její stopy dokládají stálou snahu využít zdejší zrudnění, přičemž nově se uvažuje i o těžbě polymetalických rud v této oblasti (Sadílek 2014, 13; Sadílek-Hrazdil-Houzar 2004, 145-152). Stranou pak ponechme hypotetickou těžbu zlata u vsi Zlatkov u Rožné, kde na těžbu prozatím odkazuje pouze název. Podobně hypotetická je zatím i těžba stříbra mezi Drahonínem a Víckovem (Sadílek 2014, 13). 
Již vzdálenější těžební okrsek pak představuje okolí Deblína. Těžba zmíněná k roku 1234 je sice fabulací Bočkových novodobých falz (CDM II, 268-269 č. 246; k pravosti Šebánek 1936, 477), ale v okolí Deblína se opravdu nacházejí stopy dobývání rudy. Rozsah a délka zdejší těžby nejsou přesně známy, nicméně asi nešlo o zanedbatelnou činnost. Ještě na konci středověku a v raném novověku došlo několikrát k pokusům těžbu obnovit (Houzar 2020, 7-8; Krejčířr Štrejn 1962, 195-199; Stránský a kol. 2005, 94-103; Vermouzek 1969, 16-34). Nepřímým dokladem těžby již ve 13. století může být nakonec neuskutečněná donace Gertrudy z Deblína, která v roce 1299 darovala své deblínské panství řádu německých rytírư. L. Jan, který se touto donací podrobně zabýval, konstatuje, že objem prostředků a dávek, který je v obdarování zmíněn, značně převyšoval možnosti zdejšího panství. Právě v sice nezmíněném, ovšem předpokládaném výnosu z těžby hledá zdroj značných finančních i materiálních prostředků, které jsou v rámci daru a dalších povinností zmíněny (Jan 1995, 18-19). Pro nás je důležité, jak jsme uvedli výše, že Demeter z Bukova deblínské panství získal sňatkem s Gertrudou z Deblína a asi sem i trvale přesídlil, jak dokládá jeho predikát z roku 1295 (CDM V, 5 č. 5). Takže pokud zde těžba na konci 13. století probíhala, jistě se jí musel účastnit.

Vzhledem k stáří rybníka a době jeho zániku by se mohlo zdát, že psané prameny, pro svoji povahu a velkou torzovitost, mají jen velice malou šanci zachytit jeho existenci. Nicméně stalo se tak. Na začátku je nutné osvětlit několik reálií ohledně historického členění zkoumaného území. Zkoumaný rybník se dnes nachází na katastrálním území obce Střítež, stejně jako blízký hrad Bukov. Nicméně rybník s nedalekou osadou Nivy, která leží na levobřeží Bukovského potoka, původně spadal pod Habří. Již výše jsme psali o poněkud výjimečném statusu Habří, které je zmíněno poprvé v roce 1342 (CDM VI, 314 č. 432). Celou tuto drobnou vesnici totiž tvořily svobodně držené dvory. Povaha této držby, jak jsme zmínili, vedla k tomu, že majetkové převody jednotlivých dvorů se zapisovaly do zemských desk. Sice se tak dělo nejspíše jen občas, ale i tak tyto zápisy dokládají alespoň v nějaké podobě majetkové poměry v této vesnici. Pro nás je navíc zvláště důležité, že se tak dělo nejen ve středověku, ale i v novověku. Díky tomu totiž víme, že území okolo dnešní osady Nivy náleželo k Habří. Samotná osada vznikla až na počátku 18. století, kdy asi pro rozrod rodiny Kř́žz̊ na jednom z haberských dvorů došlo k vybudování nové osady, která měla posloužit jejich mladším členům. Pro nás je důležité dědické vyrovnání z roku 1716 mezi Františkem Křižem, majitelem svobodného dvora v Habří, a jeho mladším bratrem Michalem. Tomu je v rámci dědictví určeno místo pro stavbu nové chalupy spolu s dvaceti měrami polí a dvěma loukami. Jedna z těchto luk se nazývala Doktora a dědické urovnání uvádí, že se tato louka nachází na místě paseky pod hrází rybníka Demalka. Zmínka o rybníku a jeho název se jistě týkají reliktu vodního díla, které zkoumáme. Dále doplňme, že podle pamětníků z Niv se zmíněná louka jmenovala Doktora podle pramene léčivé vody, který zde vyvěral (Zábrša 2013, 161-162, 169-170). Polohu rybníka jsme tedy ověrili rovněž u obyvatel Niv a shodovala se s jejich rodinnou tradicí. ${ }^{3}$ Pouze doplňme, že v majetku rodiny Kř́ižůn, nyní již bydlících v nedalekém Bukově, se pozemek s rybníkem nachází dodnes. Žádné další písemné informace o rybníku Demalka se nám v jiných zdrojích dopátrat nepovedlo.

Na okraj se ještě zastavme u názvu rybníka. Mohlo by se jednat o zkomolenou formu názvu Dejmalka, což je nedaleký vrch (603 m n. m.), který je zároveň nejvyšším bodem celého prostoru mezi říčkami Nedvědičkou, Stř́teží a Bukovem. Toponymum Dejmalka pak může souviset se jménem Dejmal, které je v jiné části Vysočiny, v okolí Havlíčkové Borové, spojováno s těžbou a zpracováním železných rud (SPJMS). Teoreticky by mohlo souviset i s lesními řemesly, konkrétně s uhlířstvím. 


\section{Metody a analýzy}

Výzkum rybníka a jeho okolí byl založen na kombinaci terénního geomorfologického mapování, metod dálkového průzkumu Země, geofyzikální prospekce, archeologie, geoarcheologie, radiokarbonového datování a dendrochronologie. Detekce antropogenních morfologických znaků byla provedena analýzou digitálního modelu terénu (DMT) a mapována během terénního průzkumu pomocí přijímače GNSS Leica Viva GS15 (obr. 2). DMT oblasti bylo vytvořeno z dat Lidaru digitálního modelu terénu České republiky 5. generace (poskytnuto ČÚZK) v ArcGIS Pro 2.8 (Natural Neighbour, rozlišení $2 \mathrm{~m}$ ). Na základě průzkumu proběhlého v roce 1995 byla v prostoru opuštěné vodní nádrže určena i dvě místa pro provedení geofyzikální prospekce (obr. 3:1). K průzkumu byly použity pozemní georadar X3M Ramac Geoscience Malå a dvě odstíněné antény o centrální frekvenci 250 a 500 Mhz. První zkoumaná plocha byla situována v jižní části lokality (plocha A), kde se nachází mohutné těleso rybniční hráze. V těchto místech byla využita anténa o centrální frekvenci $500 \mathrm{MHz}$ s tím, že hustota měřených bodů na každém profilu byla nastavena na $0,1 \mathrm{~m}$ a jednotlivé měřené profily byly od sebe vzdáleny $0,25 \mathrm{~m}$. Druhá zkoumaná plocha (plocha B) byla definována $\mathrm{v}$ severní části lokality, kde je dodnes dobře patrná mírná terénní vlna, nejspíše v minulosti vymezující vodní dílo ze severní strany. Zde byla k prospekci využita anténa s větším hloubkovým dosahem o centrální frekvenci $250 \mathrm{MHz}$. Jednotlivé linie měření byly od sebe vzdáleny $0,5 \mathrm{~m}$, hustota měřených bodů na každém profilu byla ponechána na $0,1 \mathrm{~m}$. Nedaleko původní sondy (Hrádek 1995) v místě rozhraní hráze a opuštěné vodní nádrže byla vytyčena a vykopána nová sonda, která byla litostratigraficky zdokumentována a ovzorkována do plechových krabic za účelem datování a paleoekologického výzkumu. Datování bylo provedeno na uhlících a semenech rostlin v radiokarbonové laboratoři v Poznani a data byla následně kalibrována v programu OxCal 4.4 (Bronk Ramsey 2009) podle kalibrační křivky IntCal20 (Reimer a kol. 2020). Vzorky na pylovou analýzu byly odebrány z plechových krabic v laboratoři. Vzorky byly připraveny standardní acetylační metodou s použitím kyseliny fluorovodíkové na odstranění křemičitého obsahu (Moore-Webb-Collinson 1991). Pylový koncentrát byl počítán pod světelným mikroskopem při 400násobném zvětšení, pylová zrna byla obarvena safraninem pro vyšší kontrast. Pylový diagram byl sestaven v programu POLPAL (Nalepka-Walanus 2003). Uhlíky a rostlinné makrozbytky (semena a plody) byly vybrány z proplaveného materiálu (síto 0,25 a $2 \mathrm{~mm}$ ) a určovány pod optickým mikroskopem v dopadajícím světle (uhlíky) a pod stereoskopickým mikroskopem (semena a plody rostlin). Každý uhlík byl následně lámán ve třech směrech pro spolehlivější determinaci na základě anatomie dřeva.

\section{Výsledky}

\section{Geomorfologický a archeologický průzkum}

Terénním geomorfologickým průzkumem bylo zjištěno, že nejdříve byly uloženy povodňové sedimenty o mocnosti až $2 \mathrm{~m}$. Poté proběhly dvě vlny zahlubování koryta potoka, které vymezily horní, střední a dolní tok lišící se stavbou údolní nivy. Niva horního toku leží v nejsevernější části studované oblasti (obr. 2) a dosud nebyla zasažena zpětnou erozí související s ukládáním přelivových sedimentů během povodní. Většina naší zkoumané oblasti se nachází v nivě středního toku. Střední i dolní tok byly zasaženy vlnou zpětné eroze spojené se vznikem zahloubeného koryta a nivních teras jako pozůstatku degradace původní nivy. $Z$ mapy stabilního katastru z první poloviny 19. století je patrné, že na počátku středního toku byly pole a louky. To znamená, že potok zde dosáhl rovnovážného stavu vývoje koryta a spádové křivky a že eroze na horním toku dále nepokračovala (obr. 2). Níže na středním toku, v místě zaniklého rybníka, se koryto Bukovského potoka napřimuje a prochází zářezem (1,8-3,8 m hlubokým a $272 \mathrm{~m}$ dlouhým) na pravé straně údolí. Geomorfologickým průzkumem zahrnujícím mělkou sondáž bylo prokázáno, že zářez je uměle prokopaný v přilehlém údolním svahu (Hrádek 1995). Povrch takto uměle rozšířeného 


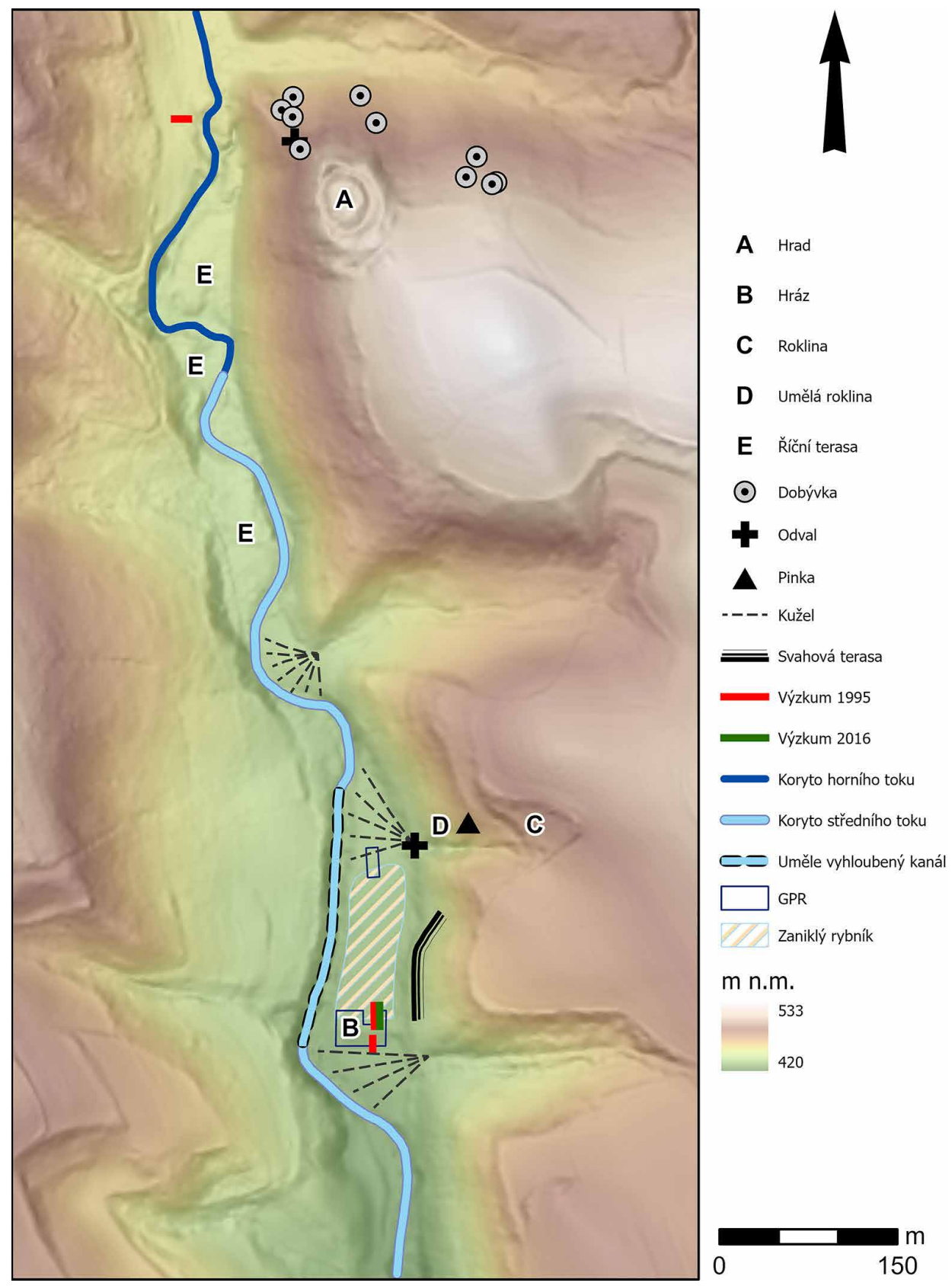

Obr. 2. Digitální model reliéfu s povrchovými antropogenními relikty a lokalizací sond.

Abb. 2. Digitales Reliefmodell mit anthropogenen Oberflächenrelikten und Lokalisierung der Sondierschnitte. 


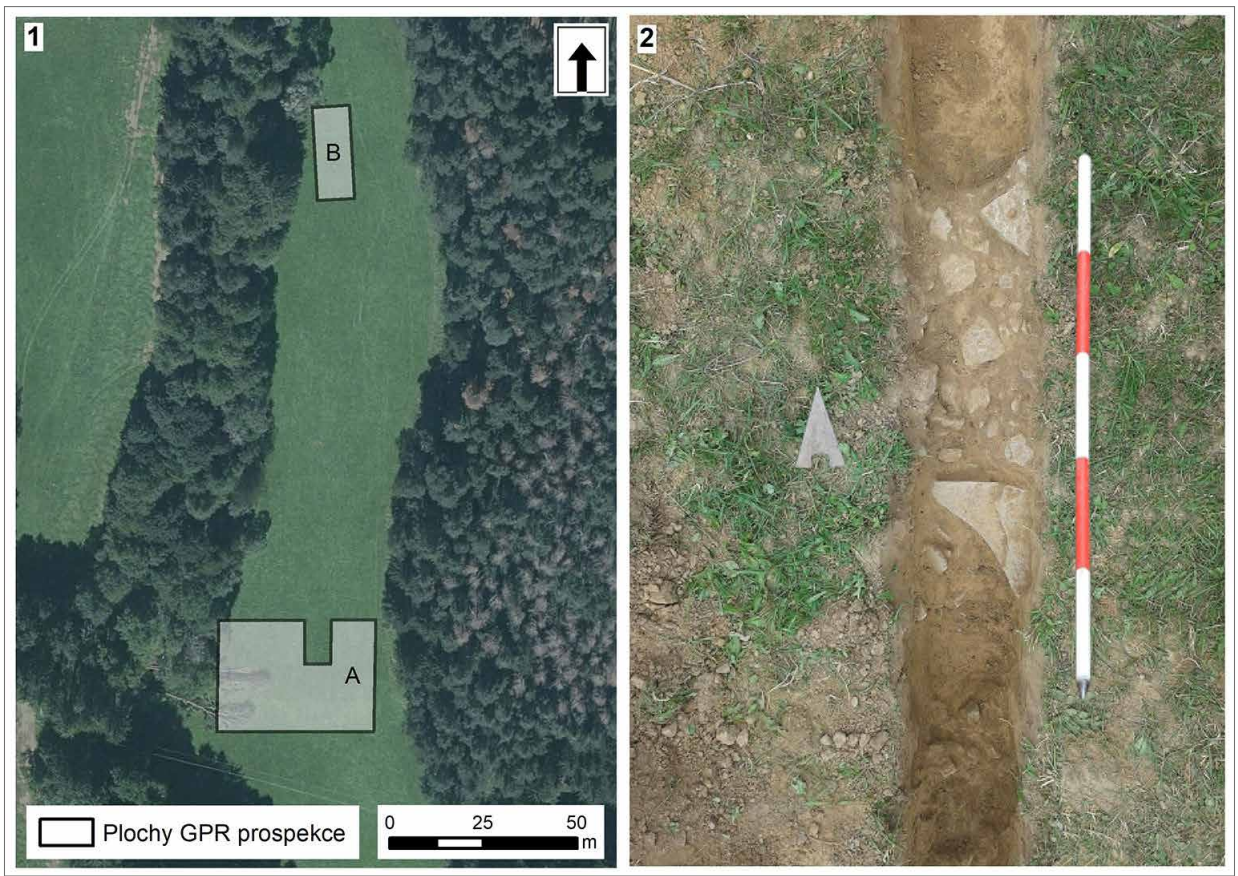

Obr. 3. 1 - rozvržení ploch GPR průzkumu; 2 - zjišt'ovací sonda v místě průběhu lineární anomálie zachycené na ploše A.

Abb. 3. 1 - Verteilung der mit Georadar (GPR) untersuchten Flächen; 2 - Feststellungssondierschnitte an den Stellen des Verlaufs der auf Fläche A festgestellten linearen Anomalien.

údolního dna je zde ukončen nízkým umělým valem naprríč údolím, který byl zjištěn již při průzkumu v roce 1995 a ověřen jako hráz středověké vodní nádrže.

V okolí rybníka proběhl i terénní průzkum antropogenních reliktů. Nad srázem levé strany údolí a na okraji výběžku vyšší svahové elevace (opyši) se nachází zřícenina hradu Bukova a zemědělské terasy. Některé povrchové relikty mohou zřejmě souviset s hornickou činností. Tomu nasvědčuje i radiokarbonové datování uhlíků objevených v jedné z dobývek, které po kalibraci odpovídá rozmezí let 1033-1206 (s pravděpodobností 95,4%). Morfologicky nejvýraznějším hornickým prvkem je pinka s odvalem při ústí lidskou rukou upravené svahové strže zasahující až k předpokládanému okraji rybníka. S hornickou činností možná souvisí i malé umělé deprese na svahu severně od zříceniny hradu (obr. 2).

\section{Geofyzikální výzkum}

Na ploše A situované v jižní části zaniklého rybníka se podařilo geofyzikálním průzkumem potvrdit přítomnost hráze, jejíž šířku lze na základě výsledků měření odhadnout na ca 10-12 m. Paralelně s ní, podél jejího jižního hřebene, se táhne výrazná lineární anomálie (obr. 4:1,3), která prochází přes zkoumanou plochu ve směru východ-západ. Nachází se těsně pod úrovní dnešního terénu, v hloubce ca $15 \mathrm{~cm}$ a v průměru dosahuje šířky ca $0,8 \mathrm{~m}$. Podle jejího charakteru lze soudit, že je tvořena kamenným materiálem, což se potvrdilo i menší zjištovací sondou o rozměrech $0,5 \times 1,5 \mathrm{~m}$, která byla situována kolmo k zachycené anomálii ve východní části zkoumané plochy (obr. 3:2). Těsně pod povrchem, zhruba v hloubce $0,1 \mathrm{~m}$, byly zachyceny zbytky kamenné destrukce o šířce $0,8 \mathrm{~m}$. Na základě těchto informací lze interpretovat zachycenou anomálii jako pozůstatek vnějšího kamenného ohrazení rybniční hráze, popřípadě jako pozůstatek zpevnění 

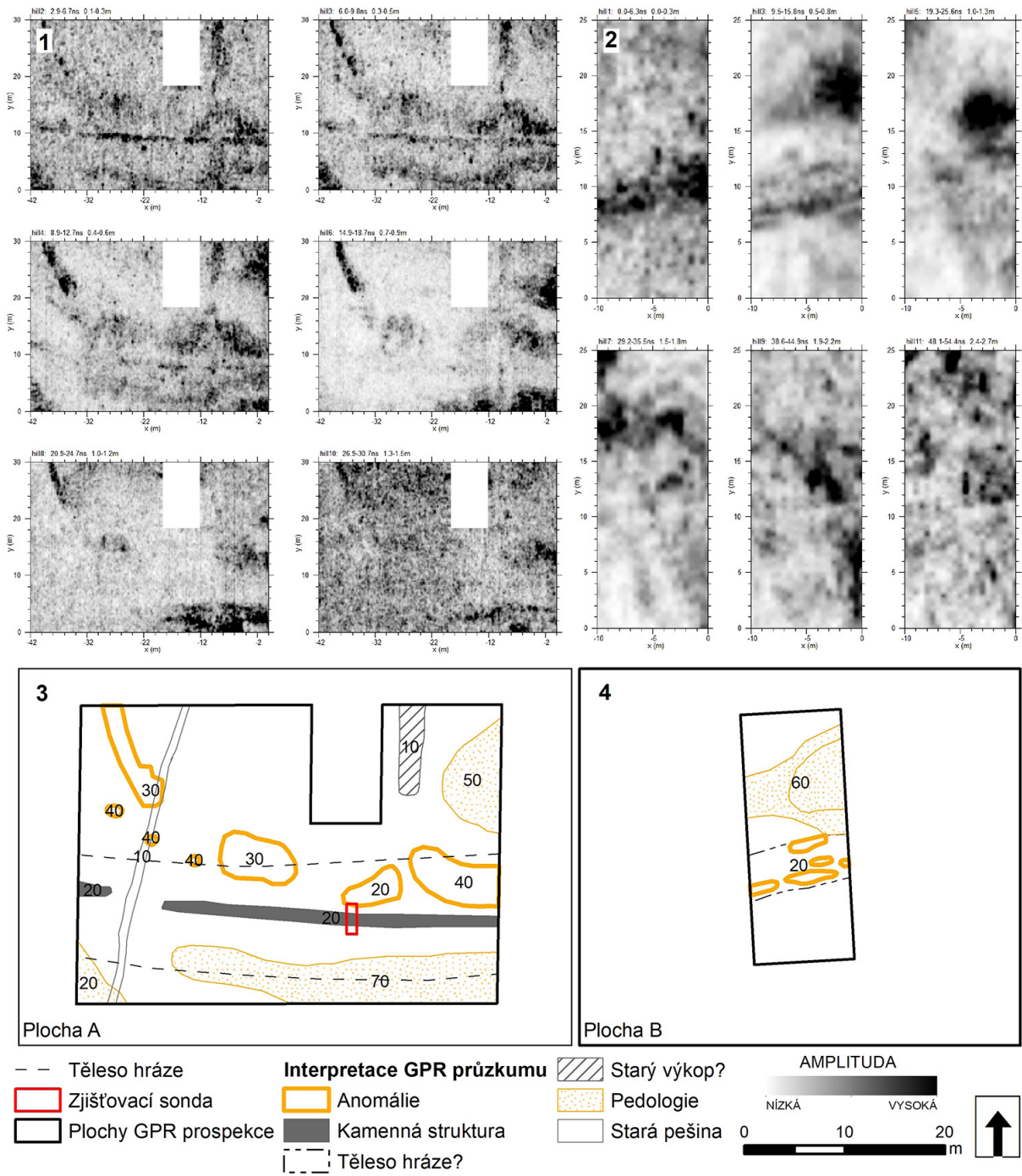

Obr. 4.1 - horizontální časové/hloubkové řezy zkoumané plochy A; 2 - horizontální časové/hloubkové řezy zkoumané plochy B; 3 - interpretace výsledků GPR průzkumu z plochy $A ; 4$-interpretace výsledků GPR průzkumu z plochy $B$.

Abb. 4. 1 - horizontale Zeit-/Tiefenschnitte der untersuchten Fläche A; 2 - horizontale Zeit-/Tiefenschnitte der untersuchten Fläche B; 3 - Interpretation der Ergebnisse der Georadaruntersuchung von Fläche A; 4 - Interpretation der Ergebnisse der Georadaruntersuchung von Fläche B.

její vnější strany. V okolí hráze se dále podařilo zachytit několik plošných anomálií, které ovšem nelze blíže interpretovat. Je ale možné, že některé z nich nějakým způsobem souvisely s konstrukcí hráze. V severovýchodní části zkoumané plochy se podařilo zachytit obdélnou anomálii, kterou lze ztotožnit se starým sondážním výkopem z roku 1995 (Hrádek 1995). Dvě rozměrné anomálie, z nichž jedna se nachází na jižní straně zkoumané plochy pod tělesem hráze a druhá na její severovýchodní straně, lze označit jako geologické útvary, např́íklad úpatní haldy svahových sedimentů. V západní části zkoumané plochy pak ve směru sever-jih prochází výraznější lineární anomálie. Jedná se o starou pěšinu. 
V místech terénní vlny v severní části rybníka (plocha B) se podařilo zachytit několik plošných anomálií, které se táhnou paralelně s tímto terénním útvarem (obr. 4:2, 4). Jejich interpretace je ovšem nejasná. Mohou i nemusí mít souvislost s lidskou činností, je však zcela jisté, že tento terénní útvar vznikl jako náplavový kužel při ústí svahové strže, rozplavením zde uloženého odvalu. Jižně od něj, tedy v místech zaniklého rybníka, je na řezu pozorovatelný sled vrstev, které lze interpretovat jako možné rybniční sedimenty. Souvrství se svažuje směrem k severu, kde je přehrazeno terénní vlnou. Na vnější straně terénní vlny pak klesá do hloubky ca $2,5 \mathrm{~m}$ od úrovně dnešního terénu a posléze se opět zvedá směrem nahoru. Jedná se pravděpodobně o zbytky původního koryta dochovaného i pod nánosy rybníka. Domnělé koryto pak z velké části vyplňuje rozsáhlá anomálie, kterou lze interpretovat jako sediment původní nivy.

\section{Geoarcheologický výzkum a konstrukce rybníka}

Nejdůležitější informace přinesla kopaná sonda, která ověřila výsledky z roku 1995 a na jejímž základě byl stanoven časový vývoj lokality a nivy. Nejspodnější část nivy je tvořena štěrky pravděpodobně pleistocenního stáŕí (jednotka 5). Následují zrnitostně variabilní sedimenty nivy složené z písčitých štěrků, písků a oglejeného šedého prachu (jednotka 4) datované do 11. až přelomu 12. a 13. století. V této jednotce byly při původním výzkumu rozpoznány uhlíky, rostlinné makrozbytky, dřevní materiál a závalky jílu, které jsou zřejmě dokladem intenzivní boční eroze v korytě meandrujícího potoka. Ta vedla $\mathrm{k}$ rozrušování břehů při degradaci nivy, při níž mohla být jejich část odstraněna. Jednotka 4 byla zachycena $v$ nivě pod sedimenty rybníka i pod tělesem hráze, kde dosahuje více než metrové mocnosti. V prostoru pod nádrží je mocnost jednotky podstatně menší, což naznačuje, že svrchní část nivy zde byla odstraněna při stavbě nebo následných úpravách. To dokládají i výsledky radiokarbonového datování uhlíků ze spodních částí tělesa hráze a báze sedimentů jednotky 3 (obr. 5). Navazující těleso sypané hráze je tvořeno na vnitřním okraji šedým prachem s vrstvičkami písku, kameny o velikosti až $50 \mathrm{~cm}$ a rozplavenými uhlíky (Hrádek 1995). Přes okraj tělesa hráze byly zaražené dřevěné jedlové piloty tvořící oporu kamenného pláště. Jedna z nich byla dendrochronologicky datována $\mathrm{k}$ roku 1194, přičemž podkorní
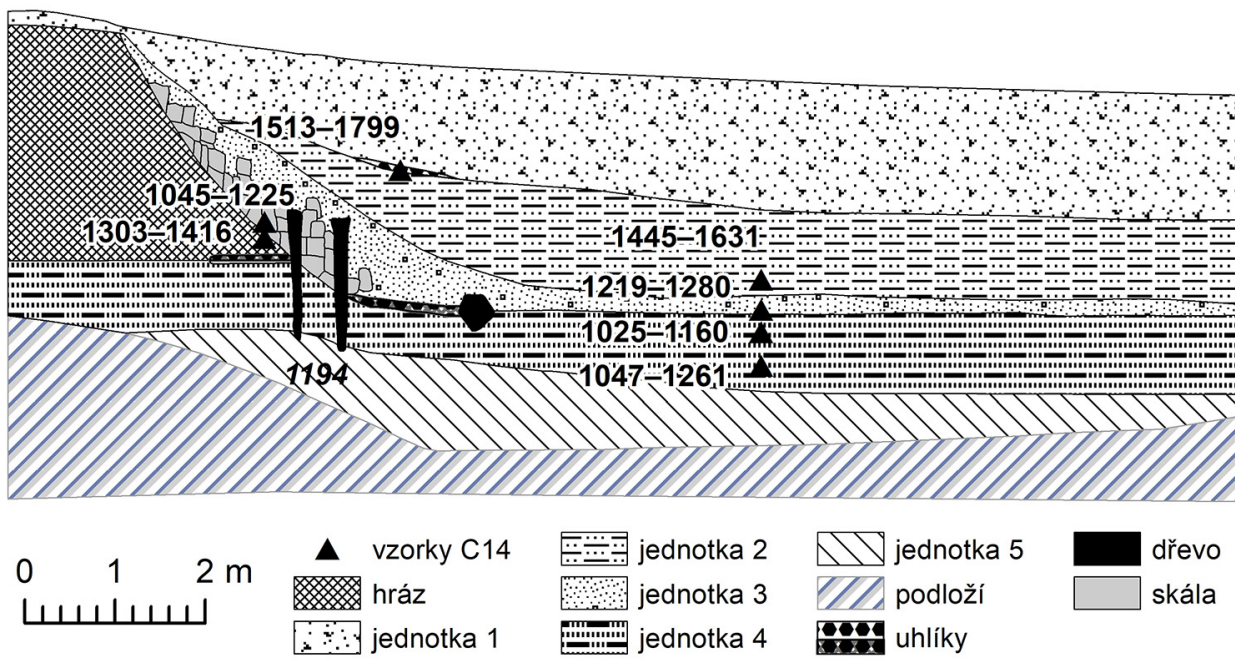

Obr. 5. Litostratigrafické schéma řezu části hráze a rybníka s výsledky radiokarbonového datování (kalibrováno podle IntCal20, AD).

Abb. 5. Litostratigraphisches Schema des Schnittes durch Damm und Teich mit Ergebnissen der Radiokarbondatierung (kalibriert nach IntCal20, AD). 
letokruh se nezachoval, ale patrně nedošlo k větší ztrátě materiálu na dřevě. Můžeme uvažovat, že chybí pouze několik málo let, maximálně deset až patnáct. Stáří piloty pravděpodobně nejlépe dokládá dobu stavby nádrže. Na rozhraní tělesa hráze a jednotky 4 a 3 byl nalezen odřezek opracovaného jedlového dřeva, který byl zřejmě během stavby nebo při pozdějších úpravách zaražen do jednotky 4 . Těleso hráze a fluviální sedimenty jednotky 4 byly překryty přechodnou jednotkou 3, koluviem tvořeným písčitým prachem. Ta vznikla po vybudování rybníka a je datována do 13. století. Následující jednotka 2 je složena z prachu s vrstvami písku. Tyto uloženiny byly akumulovány pravděpodobně v 15 . až 17 . století. Nejsvrchnější jednotka 1 je složena z prachu koluviálního původu s radiokarbonovým datem spadajícím do 16.-18. století.

\section{Vývoj vegetace od středověku do novověku}

Jednotka 4 vypovídá o vývoji vegetace před založením rybníka od 11. století až do přelomu 12. a 13. století, kdy okolní krajina byla pokryta převážně lesem (obr. 6). Pylový záznam zachycuje převahu smrku (Picea) v nivě potoka. Palynologický a antrakologický záznam ukazují také hojné zastoupení jedle (Abies) společně s bukem (Fagus) v okolním lese. Další listnaté stromy jsou méně časté, jedná se hlavně o lípu (Tilia), lísku (Corylus) nebo dub (Quercus). Př́ítomnost borovice (Pinus) jako pionýrské dřeviny naznačuje narušení lesní vegetace člověkem. Lidský vliv se odráží také v křivce pylu obilovin, v přítomnosti pelyňku (Artemisia), výskytu ruderálních a pastevních plevelů a $\mathrm{v}$ hojném zastoupení uhlíků.

V 13. století, kdy vznikla jednotka 3, se obraz krajiny a vegetace zásadně změnil (obr. 6). Došlo k odlesnění, téměř vymizely smrk, jedle a buk. Naopak mírně přibylo světlomilných pionýrských dřevin, a to borovice a lísky. Nárůst pylu trav a obilovin neomylně ukazuje přeměnu krajiny na pole a pastviny.

V období existence rybníka a jeho zaplnění sedimentem (15.-17. století) je zachycena středověká kulturní krajina téměř bez přirozených lesů (obr. 6), určitě s menší rozlohou než dnes. Intenzivní využívání krajiny je vidět v množství pylu obilovin a jejich typických plevelů koukolu (Agrostemma githago) a chrpy modráku (Centaurea cyanus), indikujících trojpolní způsob obdělávání půdy. Další pěstovanou plodinou je pohanka (Fagopyrum), která se v českých zemích šírí již od 13. století. Zachycena byla také pylová zrna lnu (Linum) a konopí (Cannabis), důležitých technických plodin středověku. Intenzivní sešlapávání a pastvu dobytka ukazují druhy, jako jsou jitrocel větší (Plantago major), rdesno ptačí (Polygonum aviculare) a štovík menší (Rumex acetosella). Pyl kopřivy (Urtica) indikuje nitrifikaci. V sedimentárním záznamu jsou zachycena vajíčka střevního parazita škrkavky (Ascaris), doklad znečištění rybníka.

Ze sedimentární výplně rybníka byl také získán soubor rostlinných makrozbytků (tab. 1) synantropních (člověka doprovázejících) druhů iniciálních stadií vegetace v polních kulturách a na rumištích, např́klad rmen rolní (Anthemis arvensis), pcháč/bodlák (Cirsium/Carduus), opletka rolní (Fallopia convolvulus), konopice širolistá (Galeopsis ladanum), konopice polní (Galeopsis tetrahit), merlík bílý (Chenopodium album), hluchavka purpurová (Lamium cf. purpureum), ptačinec žabinec (Stellaria media), penízek rolní (Thlaspi arvense) a violka rolní (Viola arvensis). Jen okrajově se uplatňovaly druhy starších sukcesních stadií rumištní vegetace, například bez černý (Sambucus nigra), bez chebdí (Sambucus ebulus) a kopřiva dvoudomá (Urtica dioica). Zaznamenány byly také druhy druhově chudých společenstev sešlapávaných a minerálních substrátů cest a sešlapávaných ploch sídlišt', např́íklad truskavec obecný (Polygonum arenastrum) a chmerek roční (Scleranthus annuus), a druhy pasek a keřových porostů, např́klad trnka (Prunus spinosa) a maliník (Rubus idaeus). Vyšší podíl synantropních druhů pozorujeme ve svrchní části profilu rybníka. Lidské aktivity indikují také druhy luk a pastvin, např́iklad trávy (Poaceae), pryskyřník plazivý (Ranunculus repens) a ptačinec trávovitý (Stellaria graminea).

Jen okrajově byly v sedimentech rybníka zaznamenány mokřadní druhy, např́íklad olše lepkavá (Alnus glutinosa) a ostřice zaječí (Carex leporina). Prostředí rybníka je v pylovém záznamu doloženo hlavně pobřežnicí jednokvětou (Litorella uniflora), jedná se o dnes vzácnou rostlinu 


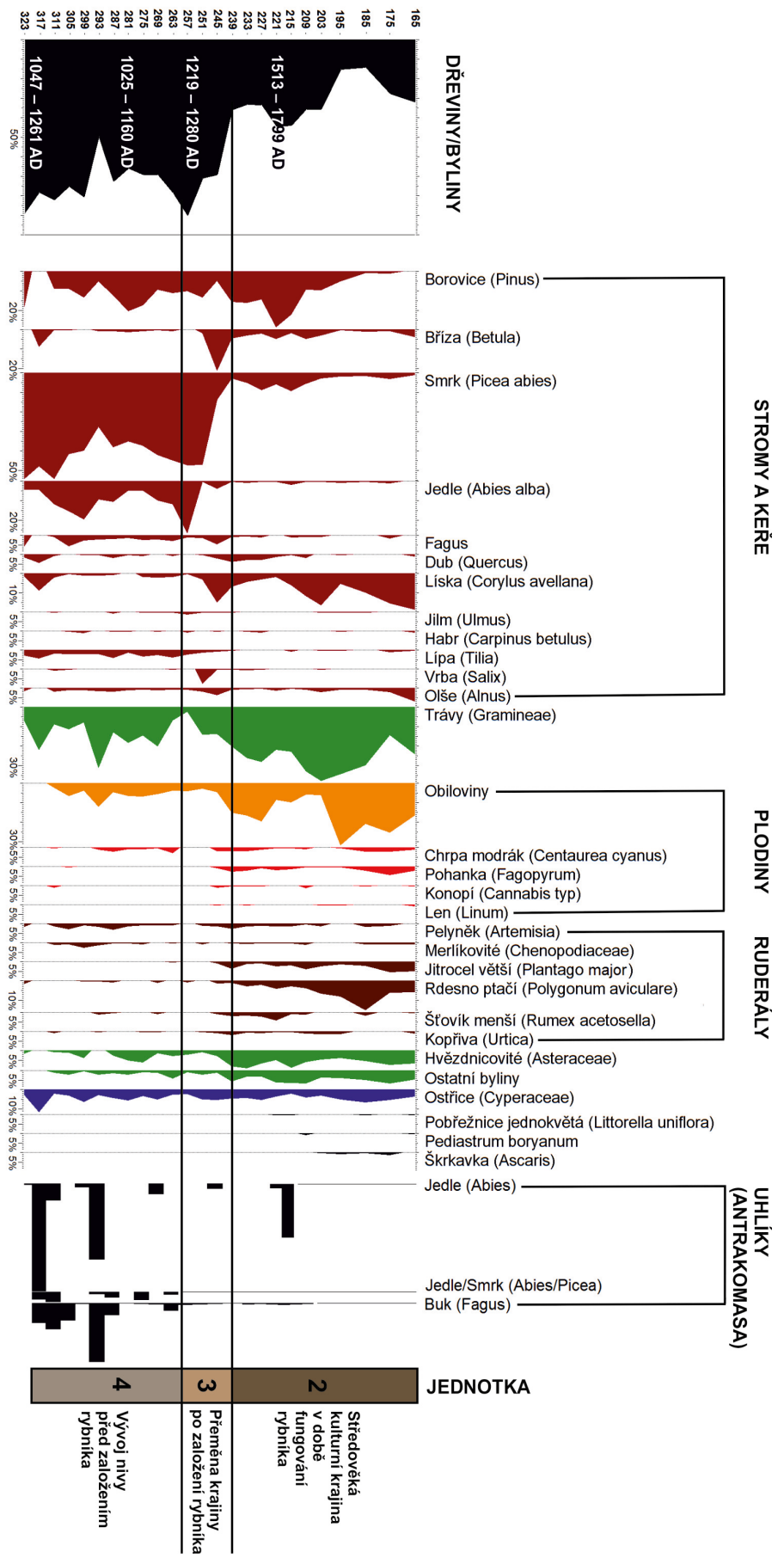

Obr. 6. Zkrácený procentuální pylový diagram s hmotnostním zastoupením uhlíků vybraných druhů dřevin, datováním a interpretacemi. Olše a ostř̌ice jsou vyloučeny z celkové sumy pylových zrn.

Abb. 6. Verkürztes prozentuales Pollendiagramm mit gewichtsmäßigem Vorkommen von Holzkohle von ausgewählten Gehölzen, Datierung und Interpretationen. Erlen und Riedgräser sind von der Gesamtsumme der Pollenkörner ausgenommen. 
vázanou na letněné dno rybníků. Vodní řasy nejsou téměř zachyceny, rybník byl obtočný bez bohaté planktonní vegetace.

\section{Diskuse}

Již z povahy dochovaných písemných pramenů a stavu archeologických výzkumů v regionu musí být mnohé naše vývody pouze diskusní povahy. Nových písemných pramenů pro 13 ., př́ípadně 12. století se asi těžko dočkáme. Naopak právě sondáž $\mathrm{v}$ místech zaniklého rybníka Demalka ukazuje budoucí potenciál archeologie ve spojení s široce pojatým environmentálním výzkumem.

\section{Kolonizace}

Již v závěru 12. století pokročila kolonizace i do této části Českomoravské vrchoviny, přičemž dosud existovaly hmotné doklady tohoto procesu pouze pro okolí řky Svratky. Z původní patrně zeměpanské držby byly zdejší majetky alespoň částečně distribuovány již někdy na přelomu 12. a 13. století. Např́íklad již k roku 1208 držela majetky v okolí pozdějšího hradu Pernštejna církev (CDB II, 73 č. 78). Již tehdy asi docházelo k zakládání prvních osad, přičemž masově probíhala kolonizace zdejšího kraje patrně až v režii jednotlivých šlechtických rodů. Na základě písemných pramenů ovšem nedokážeme odhalit, zda existovala nějaká první vlna kolonizace v režii zeměpána, popř́ípadě církve, na kterou by následně na nově nabytých majetcích navazovala šlechta, či zda se jednotlivé urozené osoby na kolonizaci podílely od počátku. V tomto ohledu by ovšem jejich vztah k nově kolonizovanému majetku nemusel být od počátku přímý a do jejich držby se mohl přesunout později.

Pokud pomineme Doubravník a okolí, nečetné písemné prameny se vztahují nejdříve k druhé polovině 13. století. Samotný kolonizační proces byl ovšem nastartován již mnohem dříve. A to snad již v druhé polovině 12. století či na jeho konci. Takto poměrně ranou dataci kolonizačního procesu, která spíše uniká písemným pramenům, celkově pro prostor Českomoravské vrchoviny dokládají i nové archeologicko-environmentálně pojaté výzkumy, které přinášejí i absolutní data (Hrubý a kol. 2014, 19-56; Hrubý 2019, 41-48). Tato data prozatím pocházejí většinou z kontextů vázaných na hornickou činnost, což může být ovšem dáno pouze stavem výzkumu.
Tab. 1. Výsledky archeobotanické makrozbytkové analýzy. d - diaspory (semena a plody rostlin); nd - ostatní makrozbytky kromě diaspor (jehlice a pupeny dřevin); nz - nezuhelnatělé makrozbytky; zuh - zuhelnatělé makrozbytky.

Tab. 1. Ergebnisse der Makrorestanalyse. d - Diasporen (Samen und Pflanzenfrüchte); nd - sonstige Makroreste außer Diasporen (Nadeln und Knospen von Gehölzen); nz unverkohlte Makroreste; zuh - verkohlte Makroreste.

\begin{tabular}{|c|c|c|c|c|}
\hline Bukov & & & 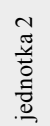 & 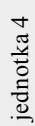 \\
\hline Abies alba & nd & $\mathrm{nz}$ & 5 & 1 \\
\hline Abies alba & nd & zuh & & 3 \\
\hline Alnus glutinosa & $\mathrm{d}$ & $\mathrm{nz}$ & 1 & \\
\hline Anthemis arvensis & $\mathrm{d}$ & $\mathrm{nz}$ & 4 & \\
\hline Carex leporina & $\mathrm{d}$ & $\mathrm{nz}$ & 1 & \\
\hline Cirsium/Caruus & d & $\mathrm{nz}$ & & 1 \\
\hline Fallopia convolvulus & d & $\mathrm{nz}$ & 1 & \\
\hline Galeopsis ladanum & d & $\mathrm{nz}$ & 1 & \\
\hline Galeopsis tetrahit & d & $\mathrm{nz}$ & & 1 \\
\hline Chenopodium album & $\mathrm{d}$ & $\mathrm{nz}$ & 49 & 1 \\
\hline Lamium cf. purpureum & $\mathrm{d}$ & $\mathrm{nz}$ & 1 & \\
\hline Picea abies & nd & $\mathrm{nz}$ & 3 & \\
\hline Picea abies & nd & zuh & & 1 \\
\hline Poaceae & d & $\mathrm{nz}$ & & 1 \\
\hline Polygonum arenastrum & $\mathrm{d}$ & $\mathrm{nz}$ & 24 & 5 \\
\hline Prunus spinosa & d & $\mathrm{nz}$ & 1 & \\
\hline Ranunculus repens & d & $\mathrm{nz}$ & 2 & 10 \\
\hline Rubus idaeus & $\mathrm{d}$ & $\mathrm{nz}$ & & 3 \\
\hline Sambucus ebulus & d & $\mathrm{nz}$ & 1 & \\
\hline Sambucus nigra & d & $\mathrm{nz}$ & & 1 \\
\hline Scleranthus annuus & $\mathrm{d}$ & $\mathrm{nz}$ & 15 & \\
\hline Stellaria graminea & d & $\mathrm{nz}$ & 1 & \\
\hline Stellaria media & $\mathrm{d}$ & $\mathrm{nz}$ & 2 & \\
\hline Thlaspi arvense & d & $\mathrm{nz}$ & 1 & \\
\hline Urtica dioica & d & $\mathrm{nz}$ & & 1 \\
\hline Viola arvensis & d & $\mathrm{nz}$ & 2 & 1 \\
\hline Suma & & & 115 & 30 \\
\hline
\end{tabular}


Kdo přesně řídil kolonizaci v okolí námi zkoumaného rybníka a čí to byl majetek, nedokážeme na základě písemných pramenů dovodit. Pouze hypoteticky můžeme říct, že zdejší majetek byl již na počátku 13. století v držení rodu erbu křídla - Tasovců. Snad právě poněkud tajemný Tas z listiny z roku 1235 (CDM V, 227 č. 14; CDB III/1, 147 č. 199) mohl být držitelem zdejších majetků a patrně se mohlo jednat i o předka pozdějšího jediného známého majitele blízkého hradu Bukova - Demetera. Pokud bychom tento konstrukt přijali, právě tohoto Tasa bychom mohli spojit se stavbou rybníka a snad i se započetím kolonizace blízkého okolí. Na základě indicií můžeme uvažovat o tom, že stavba sama, a snad i započatá kolonizace, mohla mít impulz v těžbě rud a vznik stabilních zemědělsky orientovaných sídel mohl být až následný. Obecně nám přijde spíše pravděpodobný tento model kolonizačního procesu z rukou šlechtických osob, které ale nemusely tuto činnost započít na vlastním majetku. Ten se mohl do jejich rukou dostat později. Možnost, že by zdejší dolování a kolonizace byly plně v režii zeměpána, se nám jeví jako méně pravděpodobná. S touto možností ale počítá například J. Sadílek, který uvažuje o královském založení hradu Bukova (Sadílek 2014, 89).

Pokud bychom se měli pokusit prostorově vyčlenit na základě výše shrnutých indicií Demeterův majetek, a tím pádem i snad starší majetek náležející blíže neznámému Tasovi či jinému Demeterovu předchůdci, můžeme snad předpokládat, že původní panství tvořil hrad Bukov, patrně s vesnicemi Bukov, Střítež, Strážek, Boleboř, Moravecké Janovice a Olší. Pokud předpokládáme, že kromě vesnic $\mathrm{v}$ bezprostřední blízkosti hradu náležely k původnímu majetku i statky pozdějšího Mitrova, mohly k původnímu majetku dále patřit, k čemuž docházíme spíše jen na základě geografické intuice, i Moravecké Pavlovice, které však byly ve 14. století v držení Pernštejnů. Podobným způsobem se dá uvažovat i o Drahonínu, který byl ve 14. století v rukou drobné šlechty. Hypoteticky by k původnímu panství mohly patřit i Habří a obě Rozsíčky. S jejich začleněním se vynořuje problematika zdejších svobodných dvorů, které ovšem mohly vzniknout až ve 14. století, právě s možným krátkodobým připadnutím bukovského panství zeměpánovi. Celkově tedy panství mohlo tvořit devět až jedenáct vesnic. I když nelze vyloučit, že původní majetek mohl být ještě větší a do 14. století se hlavně vesnice později držené drobnou šlechtou mohly odtrhnout od původní državy.

Panství o velikosti devíti až jedenácti vesnic by obecně představovalo poměrně velkou majetkovou držbu (srovnej Vohryzek-Kovár̆-Hlavica 2015, 138, Tab. 2). Nicméně situace na Vysočině je v jistém ohledu specifická. Kromě obecně menších výnosů zdejších polí byl hlavní rozdíl oproti jiným oblastem ve velikosti vesnic. Celková výměra polí u uvažovaných vesnic představovala v roce 1845 asi 1734 ha pro devět vesnic a 2142 ha pro jedenáct vesnic. Při započtení luk a pastvin se pak jednalo o 2243 ha, respektive o 2341 ha. ${ }^{4}$ Takováto výměra se mohla ve stejné době rovnat přibližně dvěma až třem vesnicím ve staré sídelní oblasti ve stejném časovém období. Navíc musíme počítat s tím, že středověký stav obdělávané plochy mohl být zcela jiný. Celkově tedy můžeme snad uvažovat o nevelkém panství s poměrně nízkou hustotou orné půdy, a tedy i nízkým počtem obyvatel, ačkoliv podle počtu vesnic situace vypadá odlišně.

Důležitou složkou středověkého osídlení okolní krajiny je hrad Bukov, který se nachází prŕmo nad rybníkem. Jak jsme již shrnuli výše, informace o hradě jsou vlivem nezpracovaného výzkumu velice problematické. Dnes všeobecně uznávaná datace existence hradu od poloviny 13. století po období okolo roku 1300 nemusí být definitivní. Spíše méně pravděpodobná nám připadá časná datace vzniku hradu v 30. až 40. letech 13 . století, tak jak ji nedávno opět představil J. Sadílek (2014, 103). Datace výzkumem nalezených architektonických článků se nám nejeví natolik průkazná, zvláště co se týče jejich horší chronologické citlivosti. Navíc byly některé články nalezeny druhotně použité $\mathrm{v}$ budově, kterou lze na základě fotografické dokumentace

4 Údaje jsou stanoveny na základě sčítacího operátu tzv. stabilního katastru. Ten je uložen v Ústředním archivu zeměměřickém a katastrálním. Dostupné z: https://ags.cuzk.cz/archiv/. 
z výzkumu považovat za mladší než zbytek dispozice. ${ }^{5}$ Dle našeho mínění nelze vyloučit, že hrad mohl vzniknout až někdy v pokročilé druhé polovině 13. století, přičemž věc může osvětlit pouze archeologicky datovatelný materiál z výzkumu; v zásadě jsou možné všechny tři varianty datování. Tak či tak předpokládáme, že zkoumaný rybník je patrně starší než hrad, který vznik1 v podobě, v jaké se dochoval, až později.

$\mathrm{V}$ souvislosti $\mathrm{s}$ hradem Bukovem byla představena i myšlenka zpracování rudy př́mo $\mathrm{v}$ areálu hradu. Tuto aktivitu ovšem považujeme spíše za nedoloženou a zvláště J. Sadílkem představené argumenty spíše za mylně interpretované. Jak již bylo řečeno, jen vyhodnocení proběhlého výzkumu může problematiku více osvětlit. V krátkosti shrňme, že zpracování rudy přímo v jádru vrcholně střredověkého kamenného hradu ve střední Evropě by bylo značně nezvyklé. I na předhradí, případně předpolí by tato aktivita překvapila, i když takové příklady existují. Strusky nalezené na hradě totiž vůbec nemusí dokazovat zpracovávání rud v areálu hradu (Konečný 1988, 67-68; Sadílek 2014, 77; Stránský 1988, 69-71). Strusky mohou samozřejmě pocházet z hypotetické hradní kovárny, či mohly být na hrad dovezeny k druhotnému využití. Stejně tak jednotlivé nálezy pyrotechnologických zařízení v rámci informací, které o nich máme, nevybočují z běžně nacházených exemplářn na jiných vrchnostenských sídlech. Ani přítomnost strusky v peci nic nedokazuje, jelikož ta se zde mohla vyskytnout ve formě tepelného akumulátoru (Dejmal 2007; 2012). Nicméně i přes nevyhodnocení výzkumu hradu zůstává jiný hlavní argument proti zpracování rudy prŕmo na hradě. Je jím množství strusky a jiného odpadu, jejž je velmi málo oproti zpracovatelským areálům, které jsou přímo zaplaveny tímto materiálem (k podobě úpravnických areálů Hrubý 2019, 113-144; k zpracování železa přímo na hradě a k jeho odpadu Kerbler 2019, 219-220). Takové množství odpadu, které by pocházelo z jakékoliv rentabilní těžby, by těžko uniklo komentáři, jakkoliv máme o výzkumu pouze dílčí zprávy. Můžeme sumarizovat, že přestože uvažujeme, že zkoumaný rybník mohl být navázán na těžbu či záměr těžby v okolí pozdějšího hradu Bukova, sám hrad nemusel být $\mathrm{s}$ touto aktivitou ani se vznikem rybníka současný. Dále jsme přesvědčeni, že hrad jistě nesloužil př́ímo ke zpracování rudy či následných produktů, a pokud byl do této aktivity zapojen, pak v podobě ochrany této činnosti a možné tezaurace výsledků těžby, přitom byl zároveň i centrem širšího panství a plnil další běžné role opevněného sídla.

\section{Doba předcházející stavbě rybníka}

Pokud se zaměříme na konkrétní výsledky výzkumu, můžeme konstatovat, že první zachycená etapa vývoje středověké krajiny je reprezentována sedimenty pohřbené údolní nivy datovanými do 11. až přelomu 12. a 13. století. V tomto časovém úseku došlo $\mathrm{k}$ agradaci a následné degradaci nivy. Za př́ičinu vzniku údolní nivy ukládáním rozlivových sedimentů během povodní, plošné i hloubkové eroze a aluviálních kuželů při ústí prrítoků je považováno odlesňování během kolonizace, př́ípadně následná klimatická změna od počátku 14. století. Období agradace zřejmě odpovídá středověké teplé periodě, jejíž konec byl původně stanoven do období kolem roku 1200 (Lamb 1969), nověji 1250 (Mann a kol. 2009). Přímou lidskou přítomnost v nivě dokládá větší koncentrace uhlíků a úlomků dřeva ve zkoumaném profilu a také vivianit. Podle výsledků palynologie lze předpokládat, že území bylo extenzivně využíváno a osídleno již v tomto období, včetně pěstování obilovin. Ojedinělé makrozbytky plevelů obilnin byly zjištěny přímo v sedimentu nivy (např. violka rolní, konopice polní). Odlesnění nebylo výrazné a převládající les byl tvořen jedlí a bukem, v nivě rostl také smrk. Makrozbytková analýza doložila jednotlivé zuhelnatělé jehlice jedle a smrku př́mo v sedimentech nivy, snad se jedná o důsledek lokálního

5 Jedná se o trojprostorovou budovu uprostřed hradního jádra. Dle dochovaných fotografií z výzkumu (Sadílek 2014, 135-136, 138-139), které v současnosti představuji jedinou dostupnou dokumentaci k stavbě, se zdá, že budova v areálu je mladší a časově s okolními budovami nesouvisí. Navíc svým charakterem až nápadně připomíná vesnický trojprostorový dům, včetně otopného zařízení. Mohlo by se tedy hypoteticky jednat i o mladší stavbu stojící na zaniklém hradě, přičemž ve věci může udělat jasno jen vyhodnocení proběhlého archeologického výzkumu. 
vypalování lesní vegetace. Zaznamenány byly také druhy lesních světlin a pasek (např. maliník či bez černý).

\section{Konstrukce rybnika}

Dobu stavby rybníka asi nejlépe dokládá dendrochronologické datum smýcení po roce 1194 . Na sedimentech nivy byla založena sypaná hráz, která byla z vnitřní části zesílená kamenným obložením a dřevěnými pilotami. Nelze určit, zda byla hráz v souladu s pozdějšími doporučeními založena pod úrovní tehdejšího terénu (Míka 1955, 28), ale k jejímu zahloubení až na dno nivy nedošlo. Určitě však už během stavby nebo při případném pozdějším čištění došlo k zahloubení nádrže do sedimentů původní nivy. Prachový a písčito-prachovitý materiál tvořící spolu s kamenným obložením těleso hráze je podobný sedimentům nivy v podloží rybníka, a lze tedy předpokládat, že v prostoru nádrže došlo $\mathrm{k}$ jejich odstranění a následnému použití během stavby. Okolo rybníka byl do skalního podloží částečně uměle vyhlouben kanál fungující až do současnosti jako nové koryto, zatímco část původního koryta podle výsledků geofyzikálního průzkumu plnila funkci náhonu do doby, než byla zazemněna. Ovšem vybudování rybníka mimo hlavní tok patrně není v regionu výjimečné. A stejnou situaci můžeme pozorovat například přímo pod hradem Pernštejnem, kde existovaly v poměrně úzkém údolí dokonce tři rybníky, které byly vybudovány mimo hlavní tok a napájeny náhonem (Dejmal a kol. 2021, 87). Podobný neprůtočný rybník neznámého stáří se nachází i v údolí Záskalského potoka ve Švařci u Štěpánova, kde lze uvažovat o spojitosti s těžbou na Havírně. Náš rybník byl ve srovnání s podobně zkoumaným, ovšem mladším (druhá polovina 15. století) rybníkem u obce Smolina na Valašskokloboucku konstrukčně složitější a rozsáhlejší, což je patrné také na předpokládané až dvojnásobně větší mocnosti jeho hráze (Petř́́k a kol. 2017).

\section{Fungování a zánik rybníka}

Během 13. století došlo k výrazným změnám krajiny, vodního režimu a vegetace. Změna je patrná v jednotce 3 , která pravděpodobně souvisí s konstrukcí nebo čištěním rybníka. Vzhledem $\mathrm{k}$ relativně časné dataci před rozmachem rybníkářství na přelomu 14. a 15. století (srov. Teplý 1937; Míka 1955; Hurt 1960), složité konstrukci a absenci dalších tzv. pomocných nebo chovných rybníků předpokládáme, že stavba nebyla vybudována primárně za účelem chovu ryb. Nádrž mohla sloužit jako zdroj vodního pohonu pro mechanismus, který možná souvisel se zpracováním nerostných surovin. Bohužel jakékoliv stopy výpustě či náhonu pod rybníkem jsme při výzkumu nezachytili. Voda ovšem mohla být vedena i vantroky, které nemusely zanechat $\mathrm{v}$ podstatě žádnou stopu. Se středověkou těžbou lze podle morfologie spojovat také nedalekou pinku s odvalem zasahujícím až do údolí k hornímu okraji rybníka, kde byla geofyzikálním průzkumem zachycena liniová struktura oddělující odval od prostoru nádrže. Případná těžba a zpracování rud mohlo souviset s přítomností stř́ibra, které je $\mathrm{z}$ nedalekého uranového ložiska Rožná známo ve formě agregátů Ag-tetraedritu uzavřených ve výplních hydrotermálních rudních žil (Doležalová-Losos 2004). Předpoklad souvislosti s těžbou podporuje i radiokarbonové datování uhlíků z drobných dobývek do 11. až počátku 13. století. Sedimenty uložené v klidném vodním prostředí (jednotka 2) lze spojit s obdobím fungování vodní nádrže nebo dobou, kdy rybník ztratil svoji funkci a byl zanesen sedimentem. Podle radiokarbonového datování se v nádrži ukládal sediment od 13. století pravděpodobně až do konce středověku, jak dokládají rozsahy radiokarbonového datování. Palynologie indikuje odlesněnou středověkou krajinu s obilnými poli a chovem dobytka. S prŕtomností dobytka a možným využitím jako napajedla zřejmě souvisí i známky eutorfizace a lokálního znečištění. Nápadná je také vysoká koncentrace semen truskavce obecného a chmerku ročního, druhů indikujícího sešlap, zhutňování a zraňování sedimentů např́ílad v komunikacích, průhonech pro dobytek či v místech, kde byl dobytek shromažd'ován. Pyl kopřivy indikuje 
obohacení dusíkem a eutrofizaci okolí rybníka exkrementy dobytka (viz vajíčka škrkavky). Vysokou koncentraci živin indikuje i většina dalších synantropních druhů rostlin zjištěných makrozbytkovou analýzou (k typickým patří např. rmen rolní). I přes nízké koncentrace pylu lnu a konopí zjištěné v sedimentech zkoumané vodní nádrže se jedná o zajímavý doklad zpracování přadných rostlin v povodí zkoumané vodoteče nebo prrímo v samotném rybníku. Obdobné doklady známe jen z nevelkého počtu lokalit (Petř́ík a kol. 2017; Petr-Vařeka 2019). Zpracování přadných rostlin in situ mohlo být také zdrojem živin v sedimentech rybníka. V písemných pramenech se rybník uvádí poprvé až v roce 1716, a to pod názvem Demalka. Již tehdy se uvádí jako zaniklý (Zábrša 2013, 169). Litostratigrafie ukazuje na zanesení prostoru nádrže svahovinou pravděpodobně v 16.-17./18. století (jednotka 1), v době, kdy rybník zřejmě ztratil funkci. To přibližně odpovídá tzv. Maunderovu minimu malé doby ledové. Ta je charakterizována jako období vzniku erozních i akumulačních tvarů spojených se zrychleným odtokem při souhře př́ivalových srážek a masivního odlesňování (Starkel, 2002). Je však obtížné rozlišit, zda je zvýšená tvorba strží a náplavových kuželů důsledkem odlesnění, nebo klimatické změny. Usedlosti z 13. století překryté aluviálními kužely byly nalezeny v zaniklé středověké vsi Bystřec na Drahanské vrchovině (Belcredi 2004; 2006; Hrádek 2006; 2006a). V údolí Loučky je znám př́ípad zániku vsi Nevěřín, zmiňované roku 1360, jejíž pozůstatky byly nalezeny pod nánosy kužele Drahonínského potoka (Vermouzek 1985). I u přítoků řeky Svratky existuje řada podobných př́ípadů, např́iklad zánik Starého Chlévského bahenními proudy na Chlébském potoce (Hrádek-Kallabová 2007). U Horních Louček v povodí Loučky je v první polovině 14. století doložen vznik husté sítě strží (Hrádek 2013). K tomu docházelo i v jiných částech střední Evropy, například v sousedním Bavorsku (Dotterweich a kol. 2003). $\mathrm{K}$ zániku rybníka mohla přispět také situace $\mathrm{v}$ 17. století, kdy vlivem válečných událostí trricetileté války došlo $\mathrm{k}$ značné redukci obyvatel a např́íklad nedaleká ves Bukov ztratila k polovině 17. století více než $60 \%$ obyvatel (Sadílek 2013, 41).

\section{Závěr}

Archeologický a paleoekologický výzkum Bukovského potoka ve východní části Českomoravské vrchoviny ukazuje několik fází lidských aktivit, které jsou doloženy ve zdejším paleoekologickém záznamu. To v kombinaci se získanými absolutními daty značně rozšiřuje naše znalosti o průběhu kolonizace tohoto kraje, kdy pro nejstarší období trpíme velkým nedostatkem písemných pramenů.

Lidská prrítomnost je v nivních sedimentech doložena od 11. a 12. století na základě přítomnosti uhlíků, dřev a fosfátů. Palynologicky bylo zjištěno narušování lesa člověkem a extenzivní zemědělské využívání krajiny. Zásadní změnou topografie údolního dna je vybudování rybníka někdy po roce 1194, pravděpodobně v první čtvrtině 13 . století. Po rybníku se dodnes v terénu dochovala patrná lineární struktura př́ičná k průběhu údolí, která představuje pozůstatek jeho hráze. Sondáže a vrty v předpolí hráze zachytily pozůstatek původní nivy, sedimenty rybníka a splachy pocházející z navršené hráze i okolních odlesněných svahů. Severně od lokality zasahuje z východního svahu do údolí mohutný výplavový kužel se zdrojem materiálu v prostoru pozůstatků středověké těžby. Účel výstavby rybníka není jasný. Pravděpodobně však měl sloužit jako zdroj energie pro blíže neznámý mechanismus či mechanismy. Na základě stop těžby v okolí můžeme uvažovat i o jeho souvislosti se zpracováním rud. Jako méně pravděpodobný se pak jeví chov ryb. Rybník má celkově vyspělou konstrukci. Jako poměrně náročnou akci lze pak v tomto ohledu označit vysekání nového koryta potoka, které obcházelo rybník ze západní strany, i když současnost koryta se stavbou rybníka je pouze v rovině hypotézy. Stavbu rybníka snad tedy můžeme spojit s procesem kolonizace, kdy stavebníkem mohl být nějaký neznámý předek pánů erbu křídla. $V$ tomto př́padě je pak možné, že tím neznámým mohl být i tajemný Tas z listiny z roku 1235. Patrně až později se centrem zdejšího panství stal hrad Bukov. Není vyloučeno, že rybník v té době stále sloužil svému původnímu účelu. 
Sedimenty v prostoru rybníka odráží změny krajiny v průběhu kolonizace, kterou doprovázela těžební činnost, zakládání vsí a budování hradu. Došlo k odlesnění a zániku přirozených jedlo-bukových lesů, které byly jen zčásti nahrazeny druhotnými porosty borovice a lísky. Dominantou krajiny se staly pole a pastviny. Odlesnění a intenzivnější využití krajiny způsobilo erozi, která se odráží v přítomnosti výplavových kuželů u ústí bočních údolí a zřejmě i v zaplnění nádrže sedimentem. Rybník tedy postupně ztratil svou původní funkci retenční nádrže a zanikl. Patrně se tak mohlo stát někdy v 17. století. Výzkumy v údolí Bukovského potoka potvrdily, že vývoj niv malých vrchovinných toků byl vysoce dynamický a že tato povodí rychle reagují jak na zásahy do vegetační struktury, tak i na nejrůznější klimatické změny.

Vznik tohoto článku byl podpořen v rámci projektu Historické využívání krajiny Českomoravské vrchoviny v pravěku a středověku, Programu aplikovaného výzkumu a vývoje národní kulturní identity NAKI: DF13P01OVV005, a za podpory grantu GAČR 19-14292S.

\section{Prameny}

CDB II: Codex diplomaticus et epistolaris regni Bohemiae II. 1198-1230 (Friedrich, G., ed.). Pragae 1912.

CDB III/1: Codex diplomaticus et epistolaris regni Bohemiae III/1. 1231-1238 (Friedrich, G., ed.). Pragae 1942.

CDB IV: Codex diplomaticus et epistolaris regni Bohemiae IV. 1241-1253 (Šebánek, J.-Dušková, S., edd.). Pragae 1962.

CDM II: Codex diplomaticus et epistolaris Moraviae II. 1200-1240 (Boczek, A., ed.). Olomucii 1839.

CDM IV: Codex diplomaticus et epistolaris Moraviae IV. 1268-1293 (Boczek, A., ed.). Olomucii 1845.

CDM V: Codex diplomaticus et epistolaris Moraviae V. 1294-1306 (Chytil, J., ed.). Brunae 1850.

CDM VII: Codex diplomaticus et epistolaris Moraviae V. 1334-1349 (Chytil, J., ed.). Brunae 1858.

CDM X: Codex diplomaticus et epistolaris Moraviae V. 1367-1375 (Brandl, V., ed.). Brunae 1878.

MZA Brno: Moravský zemský archiv v Brně, fond F 78 Pernštejn, č. 344, poř. č. 448.

RBM II - Regesta diplomatica nec non epistolaria Bohemiae et Moraviae II. (1253-1310) (Emler, J., ed.). Pragae 1882.

SPJMS: Slovník pomístních jmen na Moravě a ve Slezsku. Dostupné z: www.spjms.ujc,cas.cz, cit. 22. 11. 2020.

ZDB: Moravské zemské desky (Die Landtafel des Markgrafthumes Mähren) I (1348-1466) (Chlumecký, P.Chytil, J.-Demuth, K.-Wolfskron, A., edd.). Brün 1856.

\section{Literatura}

BELCREDI, L., 2004: ZSO Bystřec, usedlosti XX, XXI a XXII zaniklé na konci 13. stol. a nové poznatky o založení obce, Ve službách archeologie $\mathrm{V}, 48-62$.

- 2006: Bystřec. O založení, životě a zániku středověké vsi. Brno.

BELCREDI, L. a kol., 1989: Belcredi, L.-Čižmář, M.-Koštuř́ik, P.-Oliva, M.-Salaš, M., Archeologické lokality a nálezy okresu Brno-venkov. Brno.

BRONK RAMSEY, C., 2009: Bayesian analysis of radiocarbon dates, Radiocarbon 51 (1), 337-360. https://doi.org/10.1017/S0033822200033865

DEJMAL, M., 2007: Chlebová pec na opevněných šlechtických sídlech v ČR na př́íkladu hradu Rokštejn. Nepublikovaná bakalářská diplomová práce obhájená na ÚAM FF MU.

- 2012: Pyrotechnologická zařízení na předhradí hradu ve Veselí nad Moravou - Pyrotechnological Devices of a Bailey Castle in Veselí nad Moravou, Archeologia technica 23, 91-98.

DEJMAL, M. a kol., 2021: Dejmal, M.-Šimík, J.-Těsnohlídek, J.-Vágner, M., Archeologický výzkum a geofyzikální průzkum vrchnostenské zahrady hradu Pernštejna - Archaeological and geophysical survey of 
the castle grounds at Pernštejn. In: Pernštejnská zahrada a její památková obnova (Kalábová, L.-Konečný, M., edd.), 82-105. Brno.

DEMEK, J. a kol., 2006: Demek, J.-Mackovčin, P.-Balatka, B.-Buček, A.-Culek, M.-Čermák, P.-Dobiáš, D.-Havlíček, M.-Hrádek, M.-Kirchner, K.-Lacina, J.-Pánek, T.-Slavík, P.-Smolová, I.-Vašátko, J., Zeměpisný lexikon ČR. Hory a nížiny. Brno.

DOLEŽEL, J., 1996: Záchranné výzkumy ve stř̌edověkém jádře Doubravníku (okr. Žd’ár nad Sázavou), PV 1992, 68-72.

- 2020: Středověký areál těžby stříbra Havírna u Štěpánova nad Svratkou: dokumentace v letech 2017-2019 a problém její interpretace - Medieval silver mining area Havírna near Štěpánov nad Svratkou: Documentation in 2017-2019 and the issue of its interpretation, PV 61, č. 2, 71-112. https://doi.org/10.47382/pv0612-04

DOLEŽEL, J.-SADÍLEK, J., 2004: Středověký důlní komplex v trati Havírna u Štěpánova nad Svratkou, Příspěvek k dějinám těžby stříbra v oblasti severozápadní Moravy - Mittelalterlicher Bergbaukomplex im Flurstück Havírna bei Štěpánov nad Svratkou. Ein Beitrag zur Geschichte des Silberbergbaus in Nordwestmähren im 13. und 14. Jahrhundert, Mediaevalia archaelogica 6, 43-119.

DOLEŽALOVÁ, H.-LOSOS, Z., 2004: Sfalerit různých genetických typů sulfidického zrudnění na uranovém ložisku Rožná, Acta Mus. Moraviae, Sci. geol. LXXXIX, 91-102.

DOTTERWEICH, M. a kol., 2003: Dotterweich, M.-Schmitt, A.-Schmidtchen, G.-Bork, H. R., Quantifying historical gully erosion in northen Bavaria, Catena 50, 135-150. https://doi.org/10.1016/S0341-8162(02)00142-X

DVOŘÁK, J.-UNGER, J., 1996: Hrad Bukov ve světle studia horninového materiálu - Bukov castle in the light of study of mineral material, AR XLVIII, 513-515.

FUTÁK, P.-PLAČEK, M., 2006: Páni ze Zbraslavi a Obřan, BMD 19, $13-56$.

GRAUS, F., 1957: Dějiny venkovského lidu v Čechách v době předhusitské II. Dějiny venkovského lidu od poloviny 13. stol. do roku 1419 - История крестьянствя в Чеяии в догуситский период. Рraha.

HOUZAR, S., 2020: Regionálně-geologické postavení postavení Au-AG rudních revírů na Českomoravské vrchovině - Regional-geological position of Au-Ag ore districts in the Bohemian-Moravian Highlands, Acta rerum naturalium 25, 1-14.

HRÁDEK, M., 1995: Upřesnění geomorfologického vývoje v zájmovém území lokality Skalka. Ústav geoniky AV ČR Ostrava.

- 2006: Odezva př́irodního prostředí v okolí Bystřece na odlesnění krajiny. In: Belcredi, L., Bystřec. O založení, životě a zániku středověké vsi, 416-422. Brno.

- 2006a: Příčiny a následky ničivých povodní během kolonizace vrchovin ve 13. a 14. stol. In: Geomorfologické výzkumy v roce 2006 (Létal, A.-Smolová, I., edd.), 60-64. Olomouc.

- 2013: Relief krajiny v katastrálním území Horních Louček. In: Šimek, T., Dějiny Horních Louček. Sursum.

HRÁDEK, M.-KALLABOVÁ, E., 2007: Zánik středověkých vsí historickými povodněmi: klimatické změny nebo lidské zásahy. In: Fyzickogeografický sborník 5 (Herber, V., ed.), 81-86. Brno.

HRUBÝ, P., 2019: Metalurgická produkční sféra na Českomoravské vrchovině v závěru přemyslovské éry Metallurgical Production Sphere in the Bohemian-Moravian Highlands at the End of the Přemyslid Era. Spisy Masarykovy univerzity v Brně. Brno.

HRUBÝ, P. a kol., 2014: Hrubý, P.-Hejhal, P.-Malý, K.-Kočár, P.-Petr L., Centrální Českomoravská vrchovina na prahu vrcholného středověku. Archeologie, geochemie a rozbory sedimentárních výplní niv - Central Bohemian-Moravian Highlands on the threshold of the High Middle Ages. Archaeology, geochemistry and the analyses of alluvial sediments. Spisy Masarykovy univerzity v Brně. Brno.

HURT, R., 1960: Dějiny rybníkářství na Moravě a ve Slezsku I., II. Ostrava.

JAN, L., 1995: Neznámá listina na deblínském panství - Unbekannte Urkunde für die Herrschaft Deblín, ČMM CXIV, 3-24.

- 2019: Reprezentace elitních vrstev selského stavu v pozdním středověku - Representation of the Elite Strata of the Peasant Estate in the Middle Ages, ČMM CXXXVIII, 95-107.

JUŘIČKA, M., 2017: Páni erbu Křídla, Dějiny a majetkové postavení předního moravského rodu ve 13. a 14. století. Nepublikovaná magisterská diplomová práce obhájená na HÚ FF MU.

KERBLER, L., 2019: Eisengewinnung und -verarbeitung auf den mittelalterlichen Burgen Feinfeld und Sachsendorf, Niederösterreich - Bloomery smelting and blacksmithing at the medieval castles of 
Feinfeld and Sachsendorf, Lower Austria, Beiträge zur Mittelalterarchäologie in Österreich 34 (2018), 205-224.

KONEČNÝ, L., 1988: Nález strusek na hradě Bukově, Zkoumání výrobních objektů a technologií archeologickými metodami 5, 67-68.

KREJČÍŘ, M.-ŠTREJN, Z., 1962: K historii dolování stř́ibra u Deblína, BMD 4, 195-199.

KUDĚLKA, Z., 1982-1983: Hrad Bukov (okr. Žd’ár nad Sázavou), hrad Bukov, Výzkum románské architektury III., SPFFBU F 26-27, 79-80.

- 1984-1985: Hrad Bukov (okr. Žd’ár nad Sázavou), hrad Bukov. Výzkum románské architektury IV., SPFFBU F 28-29, 29-31.

- 1988-1989: Hrad Bukov (okr. Žd’ár nad Sázavou), hrad Bukov. Výzkum románské architektury V., SPFFBU F 32-33, 64-65.

- 1990-1992: Hrad Bukov (okr. Žd’ár nad Sázavou), hrad Bukov. Výzkum románské architektury VI., SPFFBU F 34-36, 184-185.

KYNCL, J., 1995: Výsledky výzkumu dřev z nivních půdních profilů. Botanický ústav AV ČR. Průhonice.

- 1995a: Zpráva o výsledku dendrochronologické datace dřeva z půdního profilu nivy Bukovského potoka. Botanický ústav AV ČR, Průhonice.

LAMB, H. H., 1965: The early medieval warm epoch and its sequel, Palaeogeography, Palaeoclimatology, Palaeoecology 1, 13-37. https://doi.org/10.1016/0031-0182(65)90004-0

MACEK, J., 2002: Jagellonský věk v českých zemích 3-4. 1471-1526. Praha.

MANN, M. E. a kol., 2009: Mann, M. E.-Zhang, Z.-Rutherford, S.-Bradley, R. S.-Hughes, M. K.-Shindell, D.-Ammann, C., Faluvegi, G.-Ni, F., Global Signatures and Dynamical Origins of the Little Ice Age and Medieval Climate Anomaly, Science 326 (5957), 1256-1260.

MEZNÍK, J., 1992: Dvorové vesnice na Moravě ve 14. a 15. století - Dörfer in Mähren im 14. und 15. Jh. die aus allodialen Höfen bestanden, VVM XLIV, 439-443.

MICHAL, J., 1983: Z dějin hrádku Bukovce-Lísku a vsi Bukova - Aus der Geschite des Hausberges Bukovec-Lísek und des Dorfes Bukov (Bez. Žd’ár nad Sázavou), VVM XXXV, 175-183.

MÍKA, A., 1955: Slavná minulost českého rybníkářství. Praha.

MOORE, P. D.-WEBB, J. A.-COLLINSON, M. E., 1991: Pollen analysis. Blackwell Scientific Publications. Oxford. Second edition.

NALEPKA, D.-WALANUSZ, A., 2003: POLPAL - Program for counting pollen grains, diagram plotting and numerical analysis, Acta Palaeobot. Suppl. 2, 659-661.

PETR, L.-VAŘEKA, P., 2019: Palynology research of water reservoirs of later mediaeval and post-mediaeval deserted villages in West Bohemia, Czech Republic, Archaeological and Antropological Science 11 (8), 4059-4073. https://doi.org/10.1007/s12520-019-00809-4

PETŘÍK, J. a kol., 2017: Petř́́k, J.-Hlavica, M.-Petr, L.-Chmela, T.-Schenk, Z.-Lukšíková, H.-Milo, P.Vrla, R.-Odehnal, P.-Petrůj, Z.-Petrůj, M.-Kočár, P., Rybník jako součást hospodářství vrchnostenského panství a indikátor podoby krajiny jižního Valašska v 15. až 17. století - Fischteiche als ökonomische Bestandteile einer adeligen Grundherrschaft und als Indikator für die Landschaftsform der Mährischen Südwalachei im 15. bis 17. Jahrhundert, AH 42, 789-817. https://doi.org/10.5817/AH2017-2-19

PLAČEK, M., 1987: Sídlištní struktura a hrady v povodí Loučky (Bobrůvky). In: Vývoj obydlí, sídlišt' a sídlištní struktury na jižní Moravě. XVI. mikulovské sympozium, 245-255. Praha.

- 2001: Ilustrovaná encyklopedie moravských hradů, hrádků a tvrzí. Praha.

POLÁČEK, L., 1990: Feudální sídla v povodí Bystřice, Nedvědičky a Bobrůvky ve světle archeologických nálezů - Feudalsitze im Flussgebiet der Bystřice, Nedvědička und Bobrůvka im Lichte Archäologischer Funde. In: Pravěké a slovanské osídlení Moravy. Sborník k 80. narozeninám Josefa Poulíka, 407-425. Brno.

REIMER, P. a kol., 2020: Reimer, P.-Austin, W.-Bard, E.-Bayliss, A.-Blackwell, P.-Bronk Ramsey, C.Butzin, M., Cheng, H.-Edwards, R.-Friedrich, M.-Grootes, P.-Guilderson, T.-Hajdas, I.-Heaton, T.Hogg, A.-Hughen, K.-Kromer, B.-Manning, S.-Muscheler, R.-Palmer, J.-Pearson, C.-van der Plicht, J.Reimer, R.-Richards, D.-Scott, E.- Southon, J.-Turney, C.-Wacker, L.-Adolphi, F.-Büntgen, U.-Capano, M.-Fahrni, S.-Fogtmann-Schulz, A.-Friedrich, R.-Köhler, P.-Kudsk, S.-Miyake, F.-Olsen, J.- 
Reinig, F.-Sakamoto, M.-Sookdeo, A.-Talamo, S., The IntCa120 Northern Hemisphere radiocarbon age calibration curve (0-55 cal kBP), Radiocarbon 62 (4), 725-757. https://oi.org/10.1017/RDC.2020.41

SADÍLEK, J., 1997: Rožná (okr. Ždár nad Sázavou), Hradisko, PV 1993-1994, 234-235.

- 2013: Bukov, Historie a vývoj osídlení a stavebních památek obce. Bukov.

- 2014: Hrad Bukov - Lísek, Historie, původ a význam hradu mezi obcemi Bukov a Střítež. Bukov - Střítež.

SADÍLEK, J.-HRAZDIL, V.-HOUZAR, S., 2004: Dolování železných rud v okolí hradu Pernštejna. In:

Stř́ibrná Jihlava. K dějinám hornictví a důlních prací na Vysočině, 145-152. Jihlava.

SMOLOVÁ, M., 2009: Edice listin olomouckého biskupa Dětřicha (1284-1302). Magisterská diplomová práce obhájená na Ústavu pomocných věd historických a archivnictví FF MU.

STARKEL, L., 2002: Change in frequency of extreme events as indicator of climatic change in the holocene (in fluvial system), Quaternary international 91, 23-32. https://doi.org/10.1016/S1040-6182(01)00099-4

STÁRKOVÁ, I., ed., 2000: Geologická mapa České republiky. List 24-13, Bystřice nad Pernštejnem, $1: 50$ 000. Praha.

STRÁNSKÝ, K., 1988: Analýza strusek z hradu Bukova u Rožné nad Pernštejnem, Zkoumání výrobních objektů a technologií archeologickými metodami 5, 69-71.

STRÁNSKÝ, K. a kol., 2005: Stránský, K.-Usohal, V.-Janová, D.-Buchal, A.-Stránský, L., Deblínské rudné doly - stopy po těžbě stř́ibra a zlata, Archeologia technica 17, 94-103.

ŠEBÁNEK, J., 1936: Moderní padělky v moravském diplomatáři Bočkově do r. 1306 - III, ČMM LX, 455-499.

ŠTARHA, I., 2003: Dvě rozdílná století doubravnického kláštera - Kloster in Doubravník in Verschiedenen Momenten seines Bestehens, SPFFBU C 50, 31-52.

TEPLÝ, F., 1937: Př́́spěvky k dějinám českého rybníkářství. Praha.

TEPLÝ, J., 2016: Rod Pernštejnů za přemyslovských a lucemburských králů. Pardubice.

VERMOUZEK, R., 1969: Dolování u Deblína, ČMM LXXXVIII, 16-34.

- 1985: Vyplavené vesnice na Tišnovsku a na jižní Moravě - Durch Hochwasser vernichtete Dörfer in der Gegend von Tišnov und Südmähren, VVM XXXVII, 68-75.

VOHRYZEK, S., 2020: Dvorové vsi na jihozápadní Moravě - Curial villages in Southwest Moravia, AVV 7 (2016-2017), 59-74.

VOHRYZEK, S.-KOVÁ̌̌, J.-HLAVICA, M., 2015: K velikosti panství hradů na jihozápadní Moravě před husitskými válkami - On the extent of castle domains in Southwest Moravia before the Hussite Wars, Studia archaeologica Brunensia 20, č. 1, 133-152.

ZÁBRŠA, V., 2013: Habří - Nivy - Lopaty 1342-2012. Moravské Pavlovice.

\section{Zusammenfassung}

\section{Der Teich Demalka. Ein Beitrag zur Besiedelung des nordöstlichen Teils der Böhmisch- Mährischen Höhe im Mittelalter}

Das Aufkommen einer menschlicher Tätigkeit und die Entwicklung ihrer Intensität unterscheidet sich im nordöstlichen Teil der Böhmisch-Mährischen Höhe von den traditionellen Siedlungsgebieten in Niederungen. In dieser Region wird der Beginn der Besiedelung allgemein ins 13. Jahrhundert gelegt. Die Untersuchung des Tales des Baches Bukovský potok liefert ein viel komplizierteres Bild. Dank der Kombination von einer Reihe Verfahren und Methoden der Geländeuntersuchung stehen uns mehrere Zeitfenster menschlicher Aktivitäten zur Verfügung. Außer den eigentlichen Sedimenten, die den inneren Teil des Teichs füllen wurden auch Fluvialsedimente der Talaue untersucht. Aus den gewonnenen Daten geht hervor, dass wir mittelalterliche anthropogene Aktivitäten im Tal des Baches Bukovský potok in die Zeit ab dem 12. Jahrhundert datieren können. Palynologisch wurde für den Zeitraum vor Anlegung des Teiches und Errichtung der Burg eine Störung des Waldes durch den Menschen und eine extensive landwirtschaftliche Nutzung der Landschaft festgestellt. Der eigentliche Teich wurde irgendwann nach 1194 angelegt, 
wahrscheinlich im ersten Viertel des 13. Jahrhunderts. Es gelang, seinen Damm und den Zulauf $\mathrm{zu}$ erfassen. Interessant ist, dass er nicht direkt am Bachlauf stand, sondern von einem Zuleitungskanal gespeist wurde. Den genauen Zweck des Teichs hat die räumlich begrenzte Untersuchung nicht erlaubt herzuleiten. Jedoch kann aufgrund von Erzabbauspuren in der Umgebung auch im Zusammenhang mit dem Teich eine Erzaufbereitung in Betracht gezogen werden. Der Teich hat demnach als Kraftquelle für den Antrieb eines Aufbereitungsmechanismus dienen können. Erbauer des Teichs war offenbar ein Angehöriger der Adelsfamilie von Tasov, die diesen Landstrich wahrscheinlich kolonisiert haben. Beim Bau des Teichs kam es zur Entwaldung und dem Untergang der natürlichen Nadel-Buchenwälder, die nur teilweise durch einen sekundären Kiefer- und Haselnussbestand ersetzt wurden. Zur Dominante der Landschaft wurden Felder und Weiden. Der Teich existierte anschließend wohl bis ins 17. Jahrhundert, als er sich definitiv mit Sedimenten füllte und verschwand. Bis in die heutigen Tage hat sich nur noch eine verschwommene Kenntnis von der Existenz des Teichs bei einigen lokalen Zeitzeugen erhalten.

Der vorliegende Beitrag entstand im Rahmen des Projektes Die Historische Nutzung der Landschaft der Böhmisch-Tschechischen Höhe in der Urzeit und im Mittelalter, des Programms der angewandten Forschung und Entwicklung der nationalen kulturellen Idendität NAKI: DF13P01OVV005, sowie des Förderprojekts GAČR 19-14292S.

Mgr. Miroslav Dejmal, Ph.D., Archaia Brno z. ú., Bezručova 78/15, 60200 Brno, Česká republika, mdejmal@archaiabrno.cz, ORCID 0000-0003-1474-1996

Mgr. Jan Petřík, Ph.D., Ústav geologických věd Př́írodovědecké fakulty Masarykovy univerzity, Kotlářská 2, 61137 Brno, Česká republika, petrik.j@sci.muni.cz

Mgr. Katarína Adameková, Ústav geologických věd Přírodovědecké fakulty Masarykovy univerzity, Kotlár̆ská 2, 61137 Brno, Česká republika, katu.adamekova@gmail.com

Mgr. Libor Petr, Ph.D., Ústav botaniky a zoologie Př́rodovědecké fakulty Masarykovy univerzity, Kotlářská 2, 61137 Brno, Česká republika, petr.libor@gmail.com

Mgr. Michaela Prišt’áková, Ústav archeologie a muzeologie Filozofické fakulty Masarykovy univerzity, Arna Nováka 1, 60200 Brno, Česká republika, pristakova@mail.muni.cz

Mgr. Michal Vágner, Ph.D., Ústav archeologie a muzeologie Filozofické fakulty Masarykovy univerzity, Arna Nováka 1, 60200 Brno, Česká republika,vagnermichal@mail.muni.cz

Mgr. Petr Kočár, Oddělení př́rodních věd a archeometrie Archeologického ústavu AV ČR, Praha, v. v. i., Letenská 4, 11801 Praha 1, Česká republika, kocar@arup.cas.cz

RNDr. Mojmír Hrádek, CSc., emeritní vědecký pracovník, Česká republika, mhradek@seznam.cz

doc. Mgr. Aleš Bajer, Ph.D., Ústav geologie a pedologie Lesnické a dřevařské fakulty Mendelovy univerzity v Brně, Zemědělská 3, 61300 Brno, Česká republika, bajer@mendelu.cz

Toto dílo lze užít v souladu s licenčními podmínkami Creative Commons BY-NC-ND 4.0 International (https://creativecommons.org/licenses/by-nc-nd/4.0/legalcode). Uvedené se nevztahuje na díla či prvky (např. obrazovou či fotografickou dokumentaci), které jsou v díle užity na základě smluvní licence nebo výjimky či omezení príslušných práv. 